\title{
5-HT recruits distinct neurocircuits to inhibit hunger-driven and non-hunger-driven feeding
}

Yanlin He $\mathbb{D}^{1,8,11}$, Xing Cai ${ }^{1,9,11}$, Hailan Liu ${ }^{1}$, Krisitine M. Conde ${ }^{1}$, Pingwen Xu ${ }^{1,10}$, Yongxiang $\mathrm{Li}^{2}$, Chunmei Wang ${ }^{1}$, Meng Yu ${ }^{1}$, Yang He ${ }^{1}$, Hesong Liu ${ }^{1}$, Chen Liang ${ }^{1}$, Tingting Yang ${ }^{1}$, Yongjie Yang ${ }^{1}$, Kaifan Yu ${ }^{1}$, Julia Wang ${ }^{1}{ }^{1}$, Rong Zheng ${ }^{1}$, Feng Liu ${ }^{3}$, Zheng Sun ${ }^{4}{ }^{4,5}$,

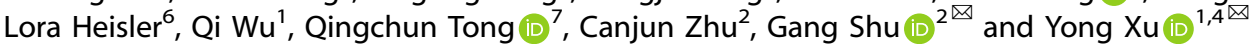

(c) The Author(s) 2021

Obesity is primarily a consequence of consuming calories beyond energetic requirements, but underpinning drivers have not been fully defined. 5-Hydroxytryptamine (5-HT) neurons in the dorsal Raphe nucleus $\left(5-\mathrm{HT}^{\mathrm{DRN}}\right)$ regulate different types of feeding behavior, such as eating to cope with hunger or for pleasure. Here, we observed that activation of 5- $\mathrm{HT}^{\mathrm{DRN}}$ to hypothalamic arcuate nucleus $\left(5-\mathrm{HT}^{\mathrm{DRN}} \rightarrow \mathrm{ARH}\right.$ ) projections inhibits food intake driven by hunger via actions at $\mathrm{ARH} 5-\mathrm{HT}_{2} \mathrm{C}$ and $5-\mathrm{HT}_{1 \mathrm{~B}}$ receptors, whereas activation of $5-\mathrm{HT}^{\mathrm{DRN}}$ to ventral tegmental area $\left(5-\mathrm{HT}^{\mathrm{DRN}} \rightarrow \mathrm{VTA}\right)$ projections inhibits non-hunger-driven feeding via actions at 5$\mathrm{HT}_{2 \mathrm{C}}$ receptors. Further, hunger-driven feeding gradually activates $\mathrm{ARH}$-projecting $5-\mathrm{H} \mathrm{T}^{\mathrm{DRN}}$ neurons via inhibiting their responsiveness to inhibitory GABAergic inputs; non-hunger-driven feeding activates VTA-projecting 5-HT ${ }^{\mathrm{DRN}}$ neurons through reducing a potassium outward current. Thus, our results support a model whereby parallel circuits modulate feeding behavior either in response to hunger or to hunger-independent cues.

Molecular Psychiatry (2021) 26:7211-7224; https://doi.org/10.1038/s41380-021-01220-z

\section{INTRODUCTION}

The prevalence of obesity has substantially increased since the 1950s. Strategies to combat obesity and related comorbidities, including type 2 diabetes, cardiovascular disease, and some types of cancer are urgently required. Obesity is primarily a consequence of the consumption of more food than the body requires; calories that are consequently stored as fat. For some individuals, overeating is primarily driven by hunger (a state of nutritional deficit), whereas others overeat in the absence of hunger [1, 2]. A better understanding of the neurobiological mechanisms for these two types of feeding behaviors is essential to develop rational precision medicines to more effectively treat the complex etiology of obesity.

The brain serotonin (5-hydroxytryptamine, 5-HT) system plays critical roles in the regulation of feeding. Brain $5-\mathrm{HT}$ is primarily synthesized by neurons in the dorsal Raphe nucleus (DRN) in the midbrain, which projects to other midbrain regions and the hypothalamus [3]. Hunger decreases 5-HT release from the DRN, while satiation increases it [4], suggesting that dynamic 5-HT bioavailability may participate in the physiological regulation of feeding behavior. Indeed, d-fenfluramine (d-Fen), a pharmacological agent that increases 5-HT content [5], showed a potent anorexigenic activity in rodents and humans [6-8]. Conversely, treatments that suppress central 5 -HT signals produce hyperphagia and weight gain [9-12]. The brain 5-HT system has been an attractive target for anti-obesity therapies. For example, d-Fen, used in combination with phentermine (as Fen/Phen), was widely prescribed obesity medication in the 1990s. The therapeutic benefit of Fen/Phen was established to be mediated primarily via $5-\mathrm{HT}_{2} \mathrm{C}$ receptors $\left(5-\mathrm{HT}_{2} \mathrm{CRs}\right)$; the $5-\mathrm{HT}_{2} \mathrm{R}$ agonist lorcaserin was clinically used to treat human obesity [13]. Recent evidence indicates that lorcaserin not only inhibits food intake triggered by hunger [14, 15], but also inhibits the consumption of high palatable foods in the absence of hunger $[15,16]$. These results suggest that the brain $5-\mathrm{HT}$ system can inhibit both hunger-driven and non-hunger-driven feeding. Although the Fen/Phen regimen [17] and lorcaserin [18] were no longer used in the clinic due to nonspecific adverse effects, better understanding about how the brain 5-HT circuitry regulates various types of feeding behaviors will provide a necessary framework to develop novel strategies to combat the obesity pandemic.

The arcuate nucleus of hypothalamus (ARH) and the ventral tegmental area (VTA) are two brain regions implicated in the control of energy homeostasis $[19,20]$ and motivated behaviors

\footnotetext{
${ }^{1}$ Children's Nutrition Research Center, Department of Pediatrics, Baylor College of Medicine, Houston, TX, USA. ${ }^{2}$ Guangdong Laboratory of Lingnan Modern Agriculture and Guangdong Province Key Laboratory of Animal Nutritional Regulation, College of Animal Science, South China Agricultural University, Guangdong, China. ${ }^{3}$ Departments of Pharmacology, University of Texas Health at San Antonio, San Antonio, TX, USA. ${ }^{4}$ Department of Molecular and Cellular Biology, Baylor College of Medicine, Houston, TX, USA. ${ }^{5}$ Department of Medicine, Division of Diabetes, Endocrinology and Metabolism, Baylor College of Medicine, Houston, TX, USA. ${ }^{6}$ Rowett Institute, University of Aberdeen, Foresterhill, Aberdeen, UK. ${ }^{7}$ Brown Foundation Institute of Molecular Medicine, University of Texas Health Science Center at Houston, Houston, TX, USA. ${ }^{8}$ Present address: Pennington Biomedical Research Center, Brain Glycemic and Metabolism Control Department, Louisiana State University, Baton Rouge, LA, USA. ${ }^{9}$ Present address: State Key

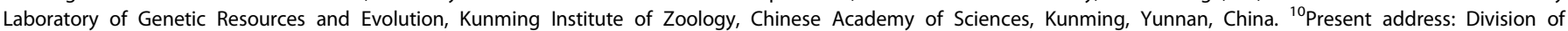
Endocrinology, Department of Medicine, The University of Illinois at Chicago, Chicago, IL, USA. ${ }^{11}$ These authors contributed equally: Yanlin He, Xing Cai. ${ }^{\bowtie}$ email: shugang@scau. edu.cn; yongx@bcm.edu
}

Received: 28 December 2020 Revised: 14 June 2021 Accepted: 29 June 2021

Published online: 21 July 2021 
7212

[21-24], respectively. Here, we characterized the neurotransmission between 5-HT ${ }^{\mathrm{DRN}}$ neurons and distinct types of neurons in the $A R H$ and VTA, and further examined the effects of the $5-\mathrm{HT}^{\mathrm{DRN}} \rightarrow \mathrm{ARH}$ and $5-\mathrm{HT}^{\mathrm{DRN}} \rightarrow$ VTA projections on hunger-driven and non-hunger-driven feeding. In addition, we assessed the dynamic changes of 5-HT ${ }^{\mathrm{DRN}}$ neuron activities during the course of hunger-driven and non-hunger-driven feeding, and delineated distinct ionic mechanisms by which $5-\mathrm{HT}^{\mathrm{DRN}}$ neurons are regulated.

\section{MATERIALS AND METHODS \\ Mice}

TPH2-CreER mice were purchased from Jackson Laboratory (\#016584) that express tamoxifen-inducible Cre recombinase selectively in 5-HT neurons, as we validated previously [25]. Dopamine transporter (DAT)-CreER mice were purchased from Jackson Laboratory (\#016583) that express tamoxifen-inducible Cre recombinase selectively in dopamine (DA) neurons, as we validated previously [25]. Tamoxifen-inducible POMCCreER mice were obtained from Dr. Joel Elmquist lab [26] and has been previously validated in the lab $[27,28]$. All these Cre lines, as well as AgRPCre mice [29], were bred with Rosa26-LSL-tdTOMATO mice [30] (Jackson Laboratory, \#007905), to generate reporter mice, and tdTOMATO signals were examined throughout the brain to confirm the expected Cre expression pattern. We also crossed TPH2-CreER onto POMC-CreER/ Rosa26-LSL-tdTOMATO, AgRP-Cre/Rosa26-LSL-tdTOMATO, or DAT-CreER/ Rosa26-LSL-tdTOMATO mice to generate compound Cre lines for CRACM studies, as described below. Some TPH2-CreER mice were used for optogenetic and fiber photometry studies as outlined below. In addition, some TPH2-CreER/Rosa26-LSL-tdTOMATO mice, as well as C57BI6j mice (purchased from the mouse facility of Baylor College of Medicine), were used for retrograde tracing and electrophysiology studies. Further, we crossed TPH2-CreER allele onto $\mathrm{Y}^{\mathrm{f} / \mathrm{f}}$ mice [31] or SK3 ${ }^{\mathrm{f} / \mathrm{f}}$ mice [32] (Jackson Laboratory, \#019083) to generate mice lacking Y2 or SK3 selectively in 5-HT neurons; littermate $\gamma 2^{\mathrm{fl} / \mathrm{f}}$ or $\mathrm{SK} 3^{\mathrm{f} / \mathrm{fl}}$ mice were used as controls. All the breeders have been backcrossed to C57Bl6j background for $>12$ generations. Mice were housed in a temperature-controlled environment in groups of two to five at $22-24^{\circ} \mathrm{C}$, using a $12 \mathrm{~h}$ light $/ 12 \mathrm{~h}$ dark cycle. All mice were fed standard chow (6.5\% fat, \#2920, Harlan-Teklad, Madison, WI) ad libitum, unless described otherwise. Water was provided ad libitum.

\section{Neurotracing}

To determine whether $5-\mathrm{HT}^{\mathrm{DRN}}$ neurons project to the ARH and VTA, 12week-old TPH2-CreER mice were anesthetized by isoflurane and received stereotaxic injections of Cre-dependent adeno-associated virus (AAV) expressing wheat germ agglutinin (WGA)-zsGreen (AAV9-CBA-DIO-WGAzsGreen, $\left.7.6 \times 10^{12} \mathrm{GC} / \mathrm{ml}\right)$ into the DRN $(200 \mathrm{nl}, 4.65 \mathrm{~mm}$ posterior, $0 \mathrm{~mm}$ lateral, and $3.6 \mathrm{~mm}$ ventral to the Bregma). These mice also received an i.p. injection of tamoxifen $(0.2 \mathrm{mg} / \mathrm{g})$ to induce Cre activity. One week after injections, mice were perfused with $10 \%$ formalin, and brain sections were cut at $25 \mu \mathrm{m}$ (five series). One series of the sections were blocked (3\% normal donkey serum) for $1 \mathrm{~h}$, incubated with goat anti-WGA antibody (1:1000; AS-2024, Vector Laboratories) on shaker at $4{ }^{\circ} \mathrm{C}$ for overnight, followed by the donkey anti-goat AlexaFluor 488 (1:200, A11055, Invitrogen) for $2 \mathrm{~h}$. Slides were cover-slipped and analyzed using a Leica DM5500 fluorescence microscope with OptiGrid structured illumination configuration.

To further confirm the projections of $5-\mathrm{HT}^{\mathrm{DRN}}$ neurons project to the ARH and VTA, 12-week-old C57BI6j mice were anesthetized by isoflurane and received stereotaxic injections of Red RetroBeads and Green RetroBeads into the ARH (bilateral $200 \mathrm{nl} / \mathrm{site}, 1.7 \mathrm{~mm}$ posterior, $0.25 \mathrm{~mm}$ lateral, and $5.9 \mathrm{~mm}$ ventral to the Bregma) and VTA (bilateral $200 \mathrm{nl} / \mathrm{site}, 3 \mathrm{~mm}$ posterior, $0.5 \mathrm{~mm}$ lateral, and $4.5 \mathrm{~mm}$ ventral to the Bregma), respectively. Four weeks after, the mice were perfused as above. Brain sections were then subjected to immunofluorescent staining for $5-\mathrm{HT}$. Briefly, sections were incubated with primary rabbit anti-5-HT antibody $(1: 10,000,20080$, ImmunoStar) overnight, followed by the goat anti-rabbit AlexaFluor 405 (1:500, A31556, Invitrogen) for $1.5 \mathrm{~h}$. The sections were mounted on glass slides and fluorescence images were analyzed using a Leica DM5500 fluorescence microscope with OptiGrid structured illumination configuration. The DRN neurons with 5-HT immunoreactivity co-labeled by Red RetroBeads, by Green RetroBeads, or by both beads were counted in ten mice.

\section{CRACM}

In order to examine the neurotransmissions between $5-\mathrm{HT}^{\mathrm{DRN}}$ neurons and POMC ${ }^{A R H}$, AgRPARH, or DA ${ }^{\mathrm{VTA}}$ neurons, we performed the channelrhodopsin-2 (ChR2)-assisted circuit mapping (CRACM), similarly as we described before [33]. Three different compound mouse strains were used: TPH2-CreER/POMC-CreER/Rosa26-LSL-tdTOMATO, TPH2-CreER/AgRPCre/Rosa26-LSL-tdTOMATO, and TPH2-CreER/DAT-CreER/Rosa26-LSL-tdTOMATO. These mice were anesthetized by isoflurane and received stereotaxic injections of Ad-iN/WED $(100 \mathrm{nl})$ and AAV-EF1a-DIO hChR2 (H134R)-enhanced yellow fluorescent protein (EYFP; $100 \mathrm{nl}$ ) into the DRN. Tamoxifen $(0.2 \mathrm{mg} / \mathrm{g}$, i.p.) was injected into these mice to induce Cre activities. After a 4-week recovery, mice were sacrificed and unfixed brain slices (containing both the DRN and ARH, or DRN and VTA, $120 \mu \mathrm{m}$ in thickness) were prepared from these mice. These brain slices were subjected to fluorescent microscopy to visualize and quantify WGA $(+)$, tdTOMATO $(+)$, and WGA $(+) /$ tdTOMATO $(+)$ neural somas in the ARH or VTA. Notably, EYFP expressed by the AAV-EF1a-DIO hChR2(H134R)-EYFP shares overlapping spectra with GFP. However, EYFP will only label the fibers and terminals in the ARH or VTA, but will not cross the synapse to label the somas of downstream neurons. Thus, the GFP-labeled somas within the ARH or VTA must be filled by WGA-GFP fusion proteins. About 500-600 neural somas were counted from each mouse and three to five mice were included for each strain. These brain slices were also used to perform electrophysiological recordings, as described below.

Under the voltage-clamp mode, light-evoked excitatory postsynaptic currents (eEPSCs) or inhibitory postsynaptic currents (elPSCs) were recorded in WGA(+)/tdTOMATO(+) neurons in the ARH or VTA in response to $473 \mathrm{~nm}$ laser blue light $(10 \mathrm{~Hz}, 10 \mathrm{~ms}$ pulse, $0.2 \mathrm{~mW}$; MBL-FN-473, CNI LASER). The eEPSCs were recorded in whole-cell voltage-clamp mode, by holding the membrane potential at $\mathrm{Vh}=-60 \mathrm{mV}$. The pipette solution containing $125 \mathrm{mM} \mathrm{CsCH}_{3} \mathrm{SO}_{3}, 10 \mathrm{mM} \mathrm{CsCl}, 5 \mathrm{mM} \mathrm{NaCl}, 2 \mathrm{mM} \mathrm{MgCl} 2,1 \mathrm{mM}$ EGTA, $10 \mathrm{mM}$ HEPES, $5 \mathrm{mM}(\mathrm{Mg})$ ATP, and $0.3 \mathrm{mM}(\mathrm{Na})_{2} \mathrm{GTP}$ (pH 7.3 with $\mathrm{NaOH})$. The elPSCs were recorded in whole-cell voltage-clamp mode, by holding the membrane potential at $\mathrm{Vh}=-70 \mathrm{mV}$. The $\mathrm{CsCl}$-based pipette solution containing of $140 \mathrm{mM} \mathrm{CsCl}, 10 \mathrm{mM}$ HEPES, $5 \mathrm{mM} \mathrm{MgCl}, 1 \mathrm{mM}$ BAPTA, $5 \mathrm{mM}(\mathrm{Mg})$ ATP, and $0.3 \mathrm{mM}(\mathrm{Na})_{2} \mathrm{GTP}$ (pH 7.30 adjusted with $\mathrm{NaOH}$; $295 \mathrm{mOsm} / \mathrm{kg})$. TTX $(1 \mu \mathrm{M})$ and 4-AP $(400 \mu \mathrm{M})$ were added to the artificial cerebrospinal fluid (aCSF), in order to confirm the response was monosynaptic responses. eEPSCs were recorded when $50 \mu \mathrm{M}$ bicuculline was applied in the bath solution; after an eEPSC was detected, $30 \mu \mathrm{M} D$ AP5 and $30 \mu \mathrm{M}$ CNQX were used to confirm the current was mediated by glutamate receptors. elPSCs were recorded when $30 \mu \mathrm{M}$ D-AP5 and $30 \mu \mathrm{M}$ CNQX were applied in the bath solution; after an eIPSC was detected, 50 $\mu \mathrm{M}$ bicuculline was used to confirm the current was mediated by $\mathrm{GABA}_{\mathrm{A}}$ receptor. Under the current-clamp mode, $30 \mu \mathrm{M}$ D-AP5, $30 \mu \mathrm{M} C N Q X$, and $50 \mu \mathrm{M}$ bicuculline were applied in the bath solution to block the glutamate and GABA inputs; action potential firing frequency and resting membrane potential were recorded in response to $473 \mathrm{~nm}$ blue light $(20 \mathrm{~Hz}, 10 \mathrm{~ms}$ pulse, $0.2 \mathrm{~mW}$ ) in the absence or presence of $100 \mu \mathrm{M} \mathrm{SB} 242084$ (a $5-\mathrm{HT}_{2 \mathrm{C}} \mathrm{R}$ antagonist) [15], or $10 \mu \mathrm{M}$ SB224289 (a 5- $\mathrm{HT}_{1 \mathrm{~B}} \mathrm{R}$ antagonist) [34]. Note that some neurons did not spontaneously fire in the presence of D-AP5, CNQX, and bicuculline cocktail, and therefore were not included in the CRACM experiments.

\section{Optogenetics and hunger-driven or non-hunger-driven \\ feeding}

TPH2-CreER mice (12 weeks of age) were anesthetized with isoflurane and received stereotaxic injections of Cre-dependent AAV expressing ChR2-YFP (AAV-EF1a-DIO hChR2(H134R)-YFP, $\left.6.2 \times 10^{12} \mathrm{VP} / \mathrm{ml}\right)$ into the DRN (200 $\mathrm{nl}$; $4.65 \mathrm{~mm}$ posterior, $0 \mathrm{~mm}$ lateral, and $3.6 \mathrm{~mm}$ ventral to the Bregma). Simultaneously, an optic fiber $(0.2 \mathrm{~mm}$ in diameter with a numerical aperture of 0.22 ) was implanted to target the $\mathrm{ARH}(1.7 \mathrm{~mm}$ posterior, 0.25 $\mathrm{mm}$ lateral, and $5.8 \mathrm{~mm}$ ventral to the Bregma) or the VTA ( $3 \mathrm{~mm}$ posterior, $0.5 \mathrm{~mm}$ lateral, and $4.3 \mathrm{~mm}$ ventral to the Bregma). Four weeks after, mice were subjected to hunger-driven feeding paradigm. Briefly, mice were singly housed with chow diet ad libitum. Mice were then fasted overnight, and chow diet was provided back to the cage at 10 a.m. next morning. Blue $(473 \mathrm{~nm}, 10 \mathrm{~ms}$ per pulse, 20 pulses per second) or yellow light (589 $\mathrm{nm}, 10 \mathrm{~ms}$ per pulse, 20 pulses per second) pulses were delivered to the ARH or VTA through the optic fiber for one hour (10-11 a.m.). To avoid damages associated with optic stimulations, we provide $10 \mathrm{~ms}$ per pulse at 20 pulses per second ( $200 \mathrm{~ms}$ per second) leaving the majority of the period unstimulated. Light power was applied at $10 \mathrm{~mW}$ for both photostimulation and photoinhibition to reach appropriate light power 
exiting the fiber tip in the brain for activation and inhibition, respectively. Food (chow) intake was measured during the stimulation period and also at 2-h time point. The same mice received blue or yellow light pulses in different trials in a crossover fashion, with a 1-week interval. The order of blue and yellow light stimulation was randomized to avoid potential sequence effects.

After the hunger-driven feeding, the same mice were then subjected to the non-hunger-driven feeding paradigm. One week before the experiment, chow-fed mice were presented with a high-fat diet (HFD) pellets (40\% fat; TD.95217, Harlan) for 1 day to avoid neophobia, and then they were maintained on chow diet ad libitum. On the experimental day, at 10 a.m., the HFD was provided to the cage, together with chow diet. Photostimulations (blue or yellow light pulses) were delivered through the optic fiber for $1 \mathrm{~h}$ (10-11 a.m.), similarly as described above. Food (chow and HFD) intake was monitored during the stimulation period and also at 2.5-h time point.

\section{Optogenetics and real-time place preference test}

Mice were subjected to the procedure room $1 \mathrm{~h}$ before the start of each test and remained in the same room throughout the test. The experimental box contained two chambers that are connected by a doorway. The two chambers were $50 \times 50 \times 25 \mathrm{~cm}$ for each with black pexiglass wall and white pexiglass floor, and connected by an opening $(12.5 \mathrm{~cm})$ in the center. In each trial, mice were allowed to explore the two chambers for half an hour (during the light cycle). After acclimation, the time spent in each chamber was recorded and analyzed for chamber preference. To validate accurate and sufficient infection of ChR2-EYFP in 5$\mathrm{HT}^{\mathrm{DRN}}$ neurons, all mice were perfused with $10 \%$ formalin. Brain sections were cut at $25 \mu \mathrm{m}$ (five series) and subjected to histological validation Only those mice with EYFP in the DRN and the fiber tract in the ARH or VTA were included in analyses.

\section{Electrophysiology}

Twelve-week-old TPH2-CreER/Rosa26-LSL-tdTOMATO mice were anesthetized by isoflurane and received stereotaxic injections of Green RetroBeads and Purple RetroBeads into the ARH and VTA (bilateral, $200 \mathrm{nl} / \mathrm{site}$ ), respectively. Four weeks after, the mice were subjected to hunger-driven or non-hunger-driven feeding paradigm as described above. For mice undergoing hunger-driven feeding, mice were sacrificed when fed ad libitum, after a 24-h fasting, or after a 24-h fasting followed by a 2-h refeeding. For non-hunger-driven feeding, mice were sacrificed immediately before or $1 \mathrm{~h}$ after they started the non-hunger-driven feeding. Briefly, mice were deeply anesthetized with isoflurane at aforementioned time points and transcardially perfused with a modified ice-cold sucrosebased cutting solution (pH 7.3) containing $10 \mathrm{mM} \mathrm{NaCl}, 25 \mathrm{mM} \mathrm{NaHCO}$, $195 \mathrm{mM}$ sucrose, $5 \mathrm{mM}$ glucose, $2.5 \mathrm{mM} \mathrm{KCl}, 1.25 \mathrm{mM} \mathrm{NaH}{ }_{2} \mathrm{PO}_{4}, 2 \mathrm{mM} \mathrm{Na}-$ pyruvate, $0.5 \mathrm{mM} \mathrm{CaCl}_{2}$, and $7 \mathrm{mM} \mathrm{MgCl}$, bubbled continuously with $95 \%$ $\mathrm{O}_{2}$ and $5 \% \mathrm{CO}_{2}$ (Ren et al., 2012). The mice were then decapitated, and the entire brain was removed and immediately submerged in the cutting solution. Slices $(250 \mu \mathrm{m})$ were cut with a Microm HM $650 \mathrm{~V}$ vibratome (Thermo Scientific). Brain slices containing the DRN were obtained for each animal (Bregma $-2.06 \mathrm{~mm}$ to $-1.46 \mathrm{~mm}$; interaural $1.74-2.34 \mathrm{~mm}$ ). The slices were recovered for $1 \mathrm{~h}$ at $34^{\circ} \mathrm{C}$ and then maintained at room temperature in aCSF (pH 7.3) containing $126 \mathrm{mM} \mathrm{NaCl}, 2.5 \mathrm{mM} \mathrm{KCl}, 2.4 \mathrm{mM}$ $\mathrm{CaCl}_{2}, 1.2 \mathrm{mM} \mathrm{NaH} \mathrm{PO}_{4}, 1.2 \mathrm{mM} \mathrm{MgCl}, 5.0 \mathrm{mM}$ glucose, and $21.4 \mathrm{mM}$ $\mathrm{NaHCO}_{3}$ ) saturated with $95 \% \mathrm{O}_{2}$ and $5 \% \mathrm{CO}_{2}$ before recording.

Slices were transferred to a recording chamber and allowed to equilibrate for at least $10 \mathrm{~min}$ before recording. The slices were superfused at $34^{\circ} \mathrm{C}$ in oxygenated aCSF at a flow rate of $1.8-2 \mathrm{ml} / \mathrm{min}$. tdTOMATO(+) neurons, co-labeled with Green or Purple RetroBeads, in the DRN were visualized using epifluorescence and IR-DIC imaging on an upright microscope (Eclipse FN-1, Nikon) equipped with a movable stage (MP285, Sutter Instrument). Patch pipettes with resistances of 3-5 $\mathrm{M} \Omega$ were filled with intracellular solution (pH 7.3) containing $128 \mathrm{mM}$ K-gluconate, $10 \mathrm{mM} \mathrm{KCl}, 10 \mathrm{mM}$ HEPES, $0.1 \mathrm{mM}$ EGTA, $2 \mathrm{mM} \mathrm{MgCl} 2,0.05 \mathrm{mM}$ Na-GTP, and $0.05 \mathrm{mM}$ Mg-ATP. Recordings were made using a MultiClamp $700 \mathrm{~B}$ amplifier (Axon Instrument), sampled using Digidata $1440 \mathrm{~A}$ and analyzed offline with pClamp 10.3 software (Axon Instruments). Series resistance was monitored during the recording, and the values were generally $<10 \mathrm{M} \Omega$ and were not compensated. The liquid junction potential was $+12.5 \mathrm{mV}$, and was corrected after the experiment. Data were excluded if the series resistance increased dramatically during the experiment or without overshoot for action potential. Currents were amplified, filtered at $1 \mathrm{kHz}$, and digitized at $20 \mathrm{kHz}$. The current-clamp mode was engaged to measure neural firing frequency and resting membrane potential. The values for resting membrane potential and firing frequency were averaged within 2min bin.

A voltage-clamp protocol was used to record the small conductance $\mathrm{Ca}^{2+}$-activated $\mathrm{K}^{+}$(SK) current as we did before $[35,36]$. Briefly, patch pipettes with resistances of 3-5 $\mathrm{M} \Omega$ were filled with intracellular solution (pH 7.3) containing $128 \mathrm{mM}$ K-gluconate, $10 \mathrm{mM} \mathrm{KCl}, 10 \mathrm{mM}$ HEPES, 0.1 mM EGTA, $2 \mathrm{mM} \mathrm{MgCl}, 0.05 \mathrm{mM}$ Na-GTP, and $0.05 \mathrm{mM} \mathrm{Mg-ATP}$. The SK tail current was evoked by a $100 \mathrm{~ms}$ depolarizing pulse from a holding potential $-60 \mathrm{mV}$ to $0 \mathrm{mV}$ and then back to $-60 \mathrm{mV}$. To measure miniature EPSC (mEPSC), the internal recording solution contained $125 \mathrm{mM}$ $\mathrm{CsCH}_{3} \mathrm{SO}_{3}, 10 \mathrm{mM} \mathrm{CsCl}, 5 \mathrm{mM} \mathrm{NaCl}, 2 \mathrm{mM} \mathrm{MgCl}, 1 \mathrm{mM}$ EGTA, $10 \mathrm{mM}$ HEPES, $5 \mathrm{mM}(\mathrm{Mg})$ ATP, and $0.3 \mathrm{mM}(\mathrm{Na}) 2 \mathrm{GTP}$ (pH 7.3 with $\mathrm{NaOH}$ ) [37]. The mEPSCs were recorded in whole-cell voltage-clamp mode, by holding the membrane potential at $\mathrm{Vh}=-60 \mathrm{mV}$ in the presence of $1 \mu \mathrm{M} T \mathrm{TX}$ and 50 $\mu \mathrm{M}$ bicuculline. The miniature IPSCs (mIPSCs) were recorded in whole-cell voltage-clamp mode by holding the membrane potential at $\mathrm{Vh}=-70 \mathrm{mV}$. The $\mathrm{CsCl}$-based pipette solution contains $140 \mathrm{mM} \mathrm{CsCl}, 10 \mathrm{mM}$ HEPES, $5 \mathrm{mM} \mathrm{MgCl}$, $1 \mathrm{mM}$ BAPTA, $5 \mathrm{mM}(\mathrm{Mg})$ ATP, and $0.3 \mathrm{mM}(\mathrm{Na})_{2} \mathrm{GTP}(\mathrm{pH} 7.30$ adjusted with $\mathrm{NaOH} ; 295 \mathrm{mOsm} / \mathrm{kg}$ ). The mIPSCs were recorded in the presence of $1 \mu \mathrm{M} T \mathrm{TX}, 30 \mu \mathrm{M}$ D-AP5, and $30 \mu \mathrm{M}$ CNQX [38]. Frequency and peak amplitude were measured using the Mini Analysis program (Synaptosoft Inc.).

\section{Validation of $\mathbf{\gamma 2}$ or SK3 deletion}

To validate selective deletion of $\gamma 2$ from 5-HT neurons, $\gamma 2-\mathrm{TPH} 2-\mathrm{KO}$ mice and control littermates were perfused with $10 \%$ formalin, and brain sections were cut at $25 \mu \mathrm{m}$ (five series). These brain sections were subjected to dual immunofluorescent staining for $\gamma 2$ and 5-HT. Briefly, sections were incubated with primary rabbit anti- $\gamma 2$ antibody $(1: 100$, NB300-190, Novus Biologicals) and primary goat anti-5-HT antibody (1:5000, 20079, ImmunoStar) overnight, followed by the donkey antirabbit AlexaFluor 594 (1:200, A21207, Invitrogen) and donkey anti-goat AlexaFluor 488 (1:500, A11055, Invitrogen) for $1.5 \mathrm{~h}$. $\gamma 2$ Immunoreactivity (red) and 5-HT immunoreactivity (green) fluorescence signals were analyzed using a Leica DM5500 fluorescence microscope with OptiGrid structured illumination configuration.

We used real-time RT-qPCR to examine levels of SK3 mRNAs in the DRN from control vs. SK3-TPH2-KO mice. To this end, the mouse brains were removed, the DRN was quickly dissected, and subjected to RNA extraction and reverse transcription using the qSript XLT CDNA SuperMix (Quanta Biosciences, 95161-025), according to the manufacturer's instruction. Briefly, $2 \mu \mathrm{l}$ of qSript XLT CDNA SuperMix was added to $8 \mu \mathrm{l}$ of each sample, and $10 \mu \mathrm{l}$ of this RT mixture were used for CDNA synthesis $\left(25^{\circ} \mathrm{C}\right.$ for $10 \mathrm{~min}, 42^{\circ} \mathrm{C}$ for $60 \mathrm{~min}$, and $85^{\circ} \mathrm{C}$ for $5 \mathrm{~min}$ ). The CDNA samples were amplified on a CFX384 Real-Time System (Bio-Rad) using SsoADV SYBR Green Supermix (Bio-Rad). Results were normalized against the expression of house-keeping gene. Primer sequences were for cyclophilin: forwardTGGAGAGCACCAAGACAGACA and reverse-TGCCGGAGTCGACAATGAT; for SK3: forward-TGTTGCACTCTTCTCCCACG and reverse-GGTCATTGAGATT AGCTGGCT.

\section{Fiber photometry}

For the fiber photometry experiments, TPH2-CreER mice (12 weeks of age) were anesthetized by isoflurane and received stereotaxic injections of pAAV9.Syn.Flex.GCaMP6m WPRE.SV40 (200 nl/site, $\left.3 \times 10^{9} \mathrm{VP} / \mathrm{ml}\right)$ into the DRN. During the same surgery, an optical fiber (fiber: core $=400 \mu \mathrm{m}$; 0.48 NA; M3 thread titanium receptacle; Doric Lenses) was implanted over the DRN $(4.65 \mathrm{~mm}$ posterior, $0 \mathrm{~mm}$ lateral, and $3.30 \mathrm{~mm}$ ventral to the Bregma, based on Franklin and Paxinos Mouse Brain Atlas). Fibers were fixed to the skull using dental acrylic and mice were allowed 3 weeks for recovery before acclimatization investigator handling for 1 week before experiments.

The fiber photometry recordings started 4-6 weeks after surgeries to allow for adequate recovery and GCaMP6m expression to stabilize. All recordings were done in the home cage of the singly housed mice that were subjected to either hunger-driven or non-hunger-driven feeding paradigm as described above. Mice were allowed to adapt to the tethered patchcord for 2 days prior to experiments and given $5 \mathrm{~min}$ to acclimate to the tethered patchcord prior to any recording. Recordings were performed during the first $5 \mathrm{~min}$ of each $30-\mathrm{min}$ bin, to avoid photobleaching. Continuous $<20 \mu \mathrm{W}$ blue LED at $465 \mathrm{~nm}$ and UV LED at $405 \mathrm{~nm}$ served as excitation light sources, driven by a multichannel hub (Doric Lenses), modulated at 211 and $330 \mathrm{~Hz}$, respectively. A $465 \mathrm{~nm}$ 
excites calcium-dependent fluorescence from GCaMP6m protein, providing a measure of neuron activity. A $405 \mathrm{~nm}$ excites calciumindependent fluorescence from GCaMP6m protein and serves as a control for movement and bleaching artifacts. The light was delivered to a filtered minicube (FMC5, Doric Lenses) before connecting through optic fibers to a rotary joint (FRJ $1 \times 1$, Doric Lenses) to allow for movement. GCaMP6m calcium GFP signals and UV autofluorescent signals were collected through the same fibers back to the dichroic ports of the minicube into a femtowatt silicon photoreceiver (2151, Newport). The digital signals were then amplified, demodulated, and collected through a lock-in amplifier (RZ5P, Tucker-Davis Technologies) [39]. The fiber photometry data was down sampled to $8 \mathrm{~Hz}$. To align acute neural responses (in seconds) to each eating bout, animals' behavior were also simultaneously recorded with a camera. We derived the values of GCaMP6 fluorescence change $\left(\Delta F / F_{0}\right)$ by calculating $\left(F_{465}-F_{0}\right) / F_{0}$, where $F_{0}$ is the baseline fluorescence signal $2 \mathrm{~s}$ prior to the onset of each eating bout [40]. The $F_{405}$ channel is used as an isosbestic fluorescence channel; we derived the values of isosbestic fluorescence change $\left(\Delta F / F_{0}\right)$ by calculating $\left(F_{405}-F_{0}\right) / F_{0}$, where $F_{0}$ is the baseline fluorescence of the $F_{405}$ channel signal $2 \mathrm{~s}$ prior to the onset of each eating bout. To evaluate the slow changes in neural activity (every $30 \mathrm{~min}$ ), we derived the values of fluorescence change $\left(\Delta F / F_{n}\right)$ by calculating $\left(F_{465}-F_{405}\right) / F_{405}$, in order to minimize the interference of bleaching artifacts [41].

\section{Statistical analyses}

The minimal sample size was predetermined by the nature of experiments. The data are presented as mean \pm SEM and/or individual data points. Statistical analyses were performed using GraphPad Prism to evaluate normal distribution and variations within and among groups. Methods of statistical analyses were chosen based on the design of each experiment and are indicated in figure legends. $P<0.05$ was considered to be statistically significant. Note that both male and female animals were included; since we did not observe sex differences, data from both sexes were pooled for statistical analyses.

\section{Study approval}

Care of all animals and procedures were approved by the Baylor College of Medicine Institutional Animal Care and Use Committee.

\section{RESULTS \\ 5-HT ${ }^{\text {DRN }}$ neurons project to the ARH and VTA}

To examine whether 5-HT DRN neurons project to the ARH and VTA, we stereotaxically injected AAV-DIO-WGA-zsGreen into the DRN of TPH2-CreER mice (with tamoxifen induction) to selectively express WGA-zsGreen in 5-HT DRN neurons (Fig. S1A, B). WGA is an anterograde trans-synaptic tracer, which can label the somas of downstream neurons that are immediately innervated by $5-\mathrm{HT}^{\mathrm{DRN}}$ terminals [42]. We observed abundant WGA-zsGreen-labeled cell bodies in the ARH and VTA (Fig. S1C, D), confirming that 5-HT DRN neurons project to both of these brain regions. Next, we sought to determine whether the ARH and VTA receive projections from the same or segregated 5-HTDRN neurons. To this end, we stereotaxically injected red and green retrograde tracers (RetroBeads) into the ARH and VTA, respectively, in the same mice (Fig. S1E, F). As expected, we detected both red and green RetroBeads in the DRN, which were colocalized with 5-HT immunoreactivity (Fig. S1G), confirming that $5-\mathrm{HT}^{\mathrm{DRN}}$ neurons project to the ARH and/or VTA. Consistent with the broad 5-HT ${ }^{\mathrm{DRN}}$-originated projections throughout the brain regions other than the ARH and VTA $[43,44]$, we noted that the majority of $5-\mathrm{HT}^{\mathrm{DRN}}$ neurons were not labeled by retrograde beads injected into the ARH and VTA (Fig. S1G, H). Thus, only a small subset of $5-\mathrm{HT}^{\mathrm{DRN}}$ neurons provide projections to the ARH and/or VTA (as co-labeled by either green beads or red beads). Within this $5-\mathrm{HT}^{\mathrm{DRN}}$ subset projecting to the ARH and/or VTA, only $13.27 \%$ have collateral projections to both regions (co-labeled by both green and red beads), while the majority project to either ARH only (33.71\%) or VTA only (53.02\%), indicating that $\mathrm{ARH}$ - and VTA-projecting $5-\mathrm{HT}^{\mathrm{DRN}}$ neurons are largely segregated (Fig. S1H).

\section{$5-\mathrm{HT}^{\mathrm{DRN}} \rightarrow$ ARH circuit inhibits hunger-driven feeding but not} non-hunger-driven feeding

We next sought to clarify the target of $5-\mathrm{HT}^{\mathrm{DRN}}$ within the $\mathrm{ARH}$. We focussed on anorexigenic pro-opiomelanocortin neurons and orexigenic agouti-related peptide neurons (POMC ${ }^{A R H}$ and AgR$\mathrm{P}^{\mathrm{ARH}}$ ) because they are essential for feeding control [45-47]. We confirmed that TPH2-CreER does not induce Cre activity in the $\mathrm{ARH}$, while POMC-CreER or AgRP-Cre does not induce Cre activity in the DRN (Fig. S2). We next stereotaxically injected Credependent AAV expressing the optogenetic ChR2-EYFP into the DRN of the compound TPH2-CreER/POMC-CreER/Rosa26-LSLtdTOMATO mice to express ChR2 specifically in $5-\mathrm{HT}^{\mathrm{DRN}}$ neurons and their fibers/terminals, which allows photostimulation. The same mice also received stereotaxic injections of Ad-iN/WED, an anterograde trans-synaptic viral tracer [42], into the DRN. Ad-iN/ WED expressed GFP-tagged WGA (WGA-GFP) in a Cre-dependent manner and therefore 5-HT ${ }^{D R N}$ neurons and their downstream neurons were labeled by WGA-GFP. WGA-labeled somas in the $\mathrm{ARH}$ were identified as the immediate targets of $5-\mathrm{HT}^{\mathrm{DRN}}$ neurons. Note that these mice also express tdTOMATO in POMC ${ }^{\mathrm{ARH}}$ neurons due to the combination of POMC-CreER and Rosa26-LSLtdTOMATO alleles. Therefore, WGA $(+)$ tdTOMATO $(+)$ neurons within the $A R H$ were identified as $5-H^{D R N}$-innervated POMC ${ }^{A R H}$ neurons, which account for $\sim 49 \%$ of POMC ${ }^{\mathrm{ARH}}$ neurons [tdTO$\operatorname{MATO}(+)$, Fig. 1A-C].

Since WGA-GFP may also travel retrogradely [48], we adopted another approach to confirm the connectivity between $5-\mathrm{HT}^{\mathrm{DRN}}$ neurons and POMC ${ }^{\mathrm{ARH}}$ neurons. CRACM was employed to examine ex vivo electrophysiological responses in ARH slices containing 5$\mathrm{HT}^{\mathrm{DRN}}$-innervated POMC ${ }^{\mathrm{ARH}}$ [WGA(+)tdTOMATO $(+)$ ] neurons from TPH2-CreER/POMC-CreER/Rosa26-LSL-tdTOMATO mice. Under voltage-clamp, we detected blue light-evoked eEPSC only in 53\% (10 out of 19) tested WGA(+)tdTOMATO $(+)$ neurons (Fig. S3A-D). The eEPSCs were mediated by glutamatergic neurotransmission as they were blocked by glutamate receptor inhibitors (CNQX and D-AP5); 4AP and TTX failed to affect the eEPSCs, confirming a monosynaptic nature (Fig. S3A-D). Interestingly, we also detected light-eIPSCs in a few (4 out of $21,19 \%)$ WGA(+)tdTOMATO(+) neurons (Fig. S3E-H). The eIPSCs were mediated by GABA neurotransmission as they were blocked by $\mathrm{GABA}_{\mathrm{A}}$ receptor inhibitors (bicuculline); 4-AP and TTX failed to affect the elPSCs, confirming a monosynaptic nature (Fig. S3E-H). These results indicate that $5-\mathrm{HT}^{\mathrm{DRN}}$ neurons provide direct glutamatergic and/or GABAergic inputs to a portion of POMC $^{A R H}$ neurons.

We then used a current-clamp mode to examine effects of blue light photostimulation on firing frequency and resting membrane potential in $5-\mathrm{HT}^{\mathrm{DRN}}$-innervated POMC ${ }^{\mathrm{ARH}}[\mathrm{WGA}(+)$ tdTOMATO $(+)]$ neurons. Since $A g R P^{A R H}$ neurons are known to provide local inhibitory GABAergic inputs to POMC ${ }^{A R H}$ neurons [49], we added $50 \mu \mathrm{M}$ bicuculline, as well as $30 \mu \mathrm{M}$ D-AP5 and $30 \mu \mathrm{M} C N Q X$, in the bath solution to block the GABAergic and glutamatergic inputs in the current-clamp recordings. We found that blue light photostimulation on the $5-\mathrm{HT}^{\mathrm{DRN}}$ fibers/terminals in the ARH caused rapid increases in firing frequency and resting membrane potential in all tested WGA(+)tdTOMATO(+) neurons (Fig. 1D-F). We next examined the 5 -HT receptor mediating this effect. These activations were completely abolished by a selective $5-\mathrm{HT}_{2} \mathrm{C}$ antagonist, $100 \mu \mathrm{M}$ SB242084. These results indicate that photostimulation of $5-\mathrm{HT}^{\mathrm{DRN}}$ terminals activates POMC ${ }^{\mathrm{ARH}}$ neurons via a 5- $\mathrm{HT}_{2} \mathrm{R}$-mediated mechanism. Notably, SB242084 also significantly reduced the baseline firing frequency and resting membrane potential (Fig. 1E, F), highlighting an excitatory effect of tonic $5-\mathrm{HT}_{2} \mathrm{C}$ actions on these anorexigenic POMC ${ }^{\mathrm{ARH}}$ neurons.

We then used a similar approach in compound TPH2-CreER/ AgRP-Cre/Rosa26-LSL-tdTOMATO mice to identify 5-HT ${ }^{\text {DRN }}$-innervated $\mathrm{AgRP}^{\mathrm{ARH}}$ neurons, which account for $\sim 32 \%$ of $\mathrm{AgRP}^{\mathrm{ARH}}$ $[\operatorname{tdTOMATO}(+)]$ neurons (Fig. 1G-I). Using the same CRACM 
A the WGA-CRACM Preparation To Study 5- $\mathrm{H}^{\mathrm{DRN}} \rightarrow$ POMCARH Synapse

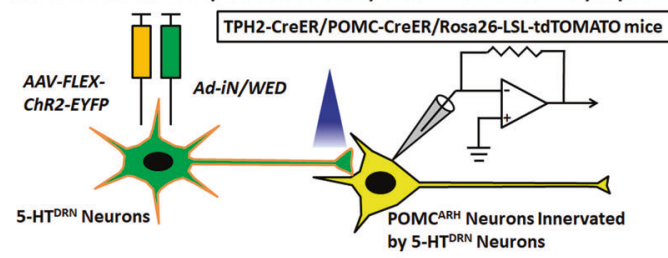

D

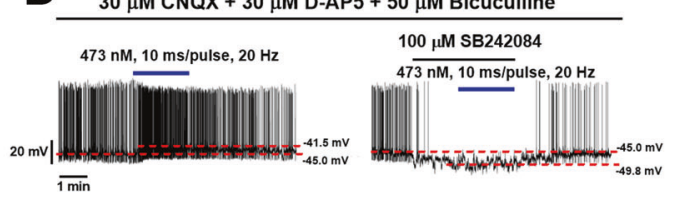

$\mathbf{G}_{\mathbf{r}}$

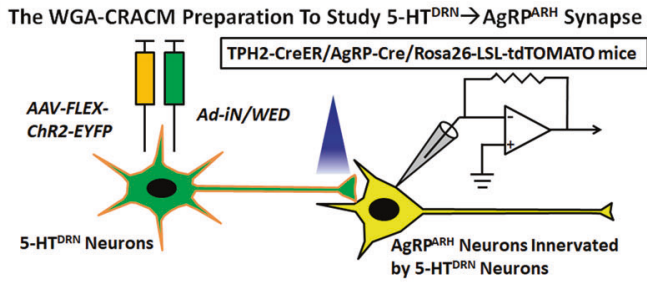

$J$

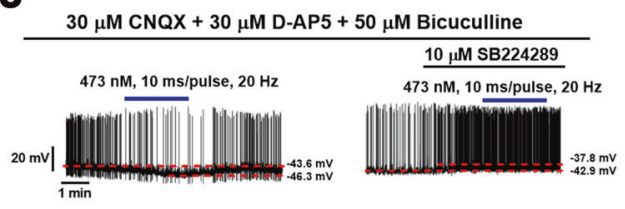

B
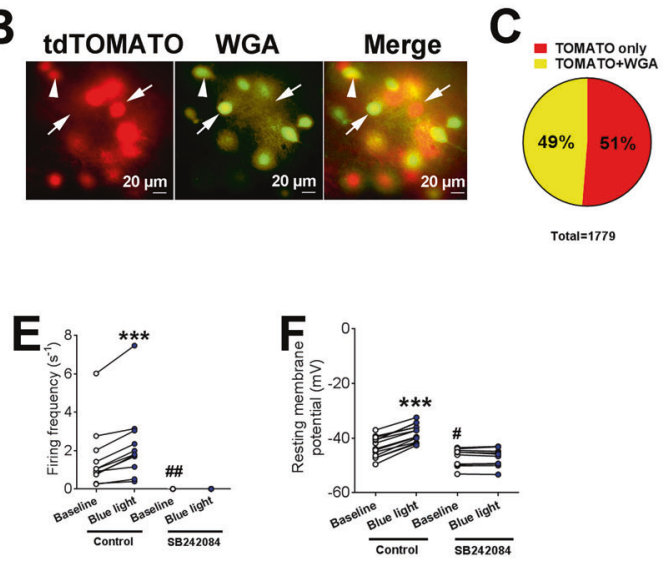

H

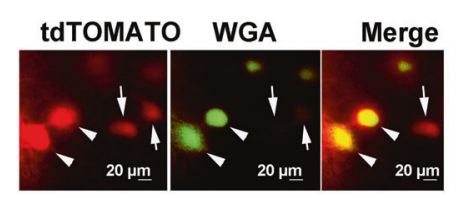

I
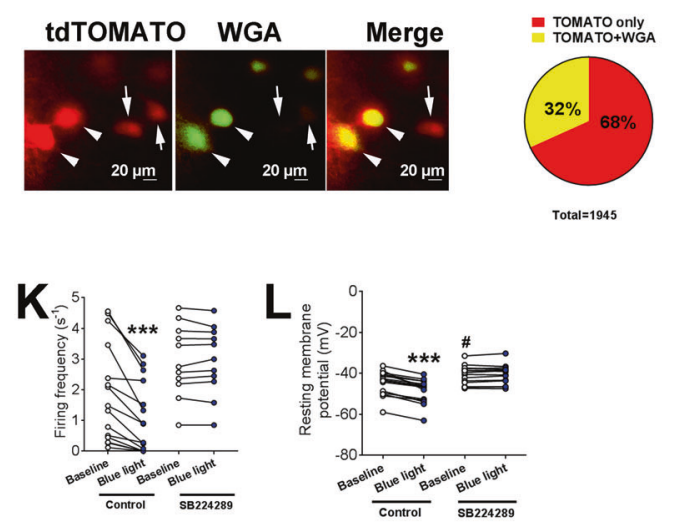

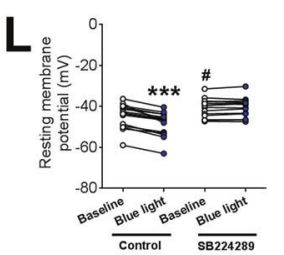

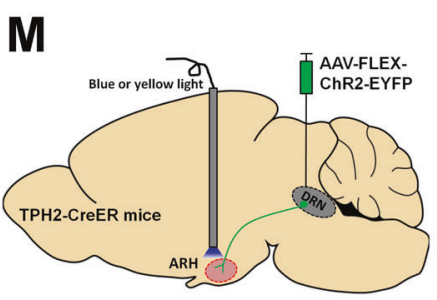

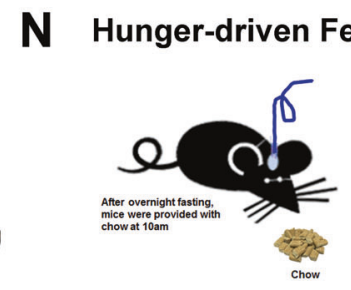

Non-hunger-
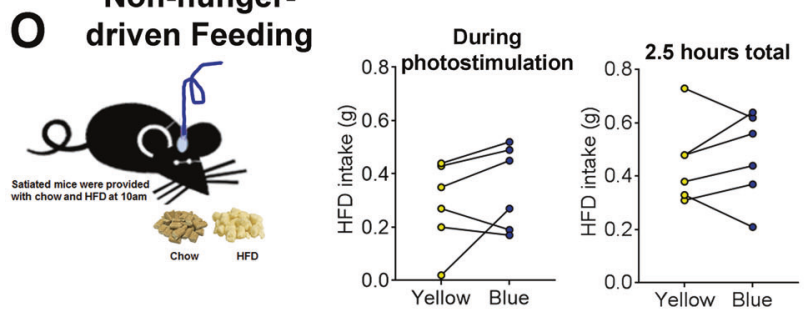

approach under the voltage-clamp protocol, we detected eEPSC in $65 \%$ (11 out of 17 ) tested WGA(+)tdTOMATO $(+)$ neurons evoked by blue light pulses (Fig. S3I-L), and detected eIPSC in 20\% (5 out of 25) tested WGA(+)tdTOMATO(+) neurons (Fig. S3M-P). Interestingly, under a current-clamp mode, we found that the blue light photostimulation caused rapid decreases in firing frequency and resting membrane potential in all tested WGA $(+)$ tdTOMATO $(+)$ neurons (Fig. 1J-L). Further, these inhibitions were completely abolished by a selective $5-\mathrm{HT}_{1 \mathrm{~B}} \mathrm{R}$ antagonist, $10 \mu \mathrm{M}$ SB224289. These results indicate that activation of $5-\mathrm{HT}^{\mathrm{DRN}}$ neurons can
$\mathbf{P}$
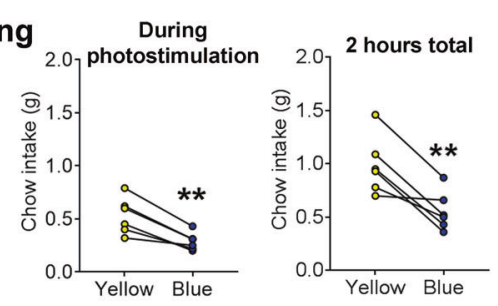

inhibit $A g R P^{A R H}$ neurons via a $5-\mathrm{HT}_{1 \mathrm{~B}} \mathrm{R}$-mediated mechanism. Notably, addition of SB224289 also significantly enhanced the baseline resting membrane potential (Fig. $1 \mathrm{~J}-\mathrm{L}$ ), highlighting an inhibitory effect of tonic 5-HT $1 \mathrm{~B}$ R actions on AgRPARH neurons.

Since $5-\mathrm{HT}^{\mathrm{DRN}}$ neurons activate anorexigenic POMC ${ }^{\mathrm{ARH}}$ neurons and inhibit orexigenic $A g R P^{A R H}$ neurons, we sought to examine the effects of $5-\mathrm{HT}^{\mathrm{DRN}} \rightarrow \mathrm{ARH}$ circuit on feeding control. To this end, we stereotaxically injected Cre-dependent AAV expressing ChR2-EYFP into the DRN of TPH2-CreER mice to express ChR2 specifically in $5-\mathrm{HT}^{\mathrm{DRN}}$ neurons and their fibers/terminals, 
Fig. $15-\mathrm{HT}^{\mathrm{DRN}} \rightarrow$ ARH circuit inhibits hunger-driven feeding but not non-hunger-driven feeding. $A$ Recordings in 5 - $\mathrm{H} \mathrm{T}^{\mathrm{DRN}}$-innervated POMC ${ }^{A R H}$ neurons [tdTOMATO $(+) W G A(+)$ ] in response to photostimulation of ChR2-labeled 5-HT ${ }^{\mathrm{DRN}}$-originated fibers within the ARH. B Representative images showing ARH neurons labeled by tdTOMATO, WGA, or both. Scale bars $=20 \mu \mathrm{m}$. Arrows point to the single-labeled neurons and the arrowhead points to a double-labeled neuron. C The composition of tdTOMATO-labeled POMC ${ }^{\text {ARH }}$ neurons that are tdTOMATO $(+)$ only and tdTOMATO $(+) W G A(+)$. A total of 1779 POMC $^{\text {ARH }}$ neurons were counted from three mice. D Representative action potential traces in response to blue light pulses $(473 \mathrm{~nm}, 10 \mathrm{~ms} /$ pulse, $20 \mathrm{~Hz})$ in the absence or the presence of $100 \mu \mathrm{M}$ SB242084 in a bath solution containing $30 \mu \mathrm{M} C N Q X, 30 \mu \mathrm{M}$ D-AP5, and $50 \mu \mathrm{M}$ bicuculline. E, F Firing frequency (E) and resting membrane potential (F) at the

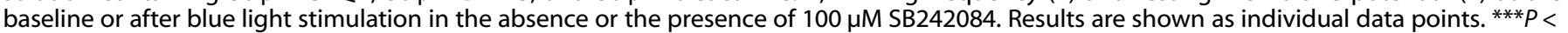
0.001 between blue light vs. baseline; $\# P<0.05$ and \#\#P<0.01 between control and SB242084 in two-way ANOVA analyses followed by Sidak post hoc test $\left(N=10-14\right.$ neurons from three mice per group). G Recordings in 5-HT ${ }^{\mathrm{DRN}}$-innervated $\mathrm{AgRP}{ }^{\mathrm{ARH}}$ neurons [tdTOMATO(+)WGA(+)] in response to photostimulation of ChR2-labeled 5-HT ${ }^{\mathrm{DNN}}$-originated fibers within the ARH. $\mathbf{H}$ Representative images showing ARH neurons labeled by tdTOMATO, WGA, or both. Scale bars $=20 \mu \mathrm{m}$. Arrows point to the single-labeled neurons and arrowheads point to double-labeled neurons. I The composition of tdTOMATO-labeled AgRPARH neurons that are tdTOMATO $(+)$ only and tdTOMATO $(+)$ WGA $(+)$. A total of 1945 $\mathrm{AgRP}^{\mathrm{ARH}}$ neurons were counted from three mice. J Representative action potential traces in response to blue light pulses (473 nm, $10 \mathrm{~ms} /$ pulse, $20 \mathrm{~Hz})$ in the absence or the presence of $10 \mu \mathrm{M}$ SB224289 in a bath solution containing $30 \mu \mathrm{M}$ CNQX, 30 $\mu \mathrm{M}$ D-AP5, and $50 \mu \mathrm{M}$ bicuculline. K, L Firing frequency $(\mathbf{K})$ and resting membrane potential $(\mathbf{L})$ at the baseline or after blue light stimulation in the absence or the presence of $10 \mu \mathrm{M}$ SB224289. Results are shown as individual data points. ${ }^{* * *} P<0.001$ between blue light vs. baseline; $\# P<0.05$ between control and SB224289 in two-way ANOVA analyses followed by Sidak post hoc test ( $N=11-15$ neurons from three mice per group). $\mathbf{M}$ Schematic experimental strategy using optogenetics to activate the $5-\mathrm{H} \mathrm{T}^{\mathrm{DRN}} \rightarrow$ ARH projections. $\mathbf{N}$ The experimental paradigm to measure hunger-driven feeding. Chow intake during photostimulation and during the total 2 -h period in mice with the 5-HTDRN $\rightarrow$ ARH projections unstimulated (yellow) or activated (blue). Results are shown as individual data points. ${ }^{* *} P<0.01$ between yellow vs. blue light in two-tailed paired $t$ test $(N=6$ mice per group). 0 The experimental paradigm to measure non-hunger-driven feeding. HFD intake during photostimulation and during the total $2.5-\mathrm{h}$ period in mice with the $5-\mathrm{HT}^{\mathrm{DRN}} \rightarrow$ ARH projections unstimulated (yellow) or activated (blue). Results are shown as individual data points ( $N=6$ mice per group). $\mathbf{P}$ Left: the experimental paradigm to measure real-time place preference in mice with the $5-\mathrm{HT}^{\mathrm{DRN}} \rightarrow \mathrm{ARH}$ projections unstimulated when in chamber 1 and activated when in chamber 2; right: the \% time spent in each chamber in mice at hungry or satiated state with or without blue light stimulation coupled to chamber 2 . Results are shown as mean \pm SEM with individual data points. ${ }^{*} P<0.01$ in two-way ANOVA analyses followed by Sidak post hoc test ( $N=6$ mice per group).

and implanted the optic fiber to target the ARH (Fig. S3Q-R). After recovery, mice were first subjected to a hunger-driven feeding paradigm. Briefly, after overnight fasting, mice were provided with chow diet at 10 a.m. next morning, while photostimulation was applied for the first hour of refeeding period (Fig. 1N). Compared to mice receiving yellow light stimulation (as a control, $589 \mathrm{~nm}, 10$ ms per pulse, $10 \mathrm{~mW}, 20$ pulses per second), mice receiving blue light stimulation $(473 \mathrm{~nm}, 10 \mathrm{~ms}$ per pulse, $10 \mathrm{~mW}, 20$ pulses per second) displayed significantly reduced chow intake during the photostimulation period and also at the 2-h time point (Fig. 1N). We then examined dark-cycle feeding in chow-fed mice which is primarily driven by hunger, and found that photostimulation of the $5-\mathrm{HT}^{\mathrm{DRN}} \rightarrow \mathrm{ARH}$ circuit also significantly inhibited dark-cycle chow intake (Fig. S3S).

We then employed a non-hunger-driven feeding paradigm. Briefly, satiated mice were provided both chow and a HFD at $10 \mathrm{a}$. m. when mice normally do not eat (Fig. 10). When provided with both chow and HFD, these satiated mice consumed primarily HFD but minimal chow (Fig. 10 and Fig. S3T), indicating that this HFD feeding is largely driven by the palatability of the HFD but rather by hunger. Importantly, there were no differences in chow or HFD intake between mice receiving yellow light or blue light stimulation (Fig. 10 and Fig. S3T). Next, we used a fasting paradigm that mice were first fasted overnight and then provided with both HFD and chow in the morning. In this setting, we found that photostimulation of the $5-\mathrm{HT}^{\mathrm{DRN}} \rightarrow \mathrm{ARH}$ circuit significantly reduced HFD intake in these hungry mice but had no effect on chow intake (Fig. S3U, V). These data suggest that the stimulation of the $5-\mathrm{HT}^{\mathrm{DRN}} \rightarrow \mathrm{ARH}$ circuit inhibits hunger-driven feeding, but has little effect on non-hunger-driven feeding behavior.

To examine the valence associated with $5-\mathrm{HT}^{\mathrm{DRN}} \rightarrow \mathrm{ARH}$ poststimulation, mice were assessed in a real-time place preference test. Briefly, mice were placed into a rectangular open field, which is comprised of two identical sides connected through an opening in the center (Fig. 1P). Without photostimulation, overnight fasted mice displayed no place preference (Fig. 1P). In the next trial, blue light pulses were paired with entry into the right compartment and fasted mice showed a preference for the blue light-paired area (Fig. 1P). However, in the satiated condition, mice did not show preference for the blue light-paired area
(Fig. 1P). These data indicate that stimulation of the $5-\mathrm{HT}^{\mathrm{DRN}} \rightarrow$ ARH circuit transmits a positive valence in hungry mice, but not in satiated mice, suggesting that the reduction in hunger-driven feeding is not due to the mice feeling unwell.

\section{$5-\mathrm{HT}^{\mathrm{DRN}} \rightarrow$ VTA circuit inhibits non-hunger-driven feeding but not hunger-driven feeding}

We next examined the effect of $5-\mathrm{HT}^{\mathrm{DRN}}$ innervation of neurochemically defined DA neurons within the VTA (DA VTA neurons) because they are a key mediator of reward-related behaviors. We confirmed that TPH2-CreER does not induce Cre activity in the VTA, while the DAT-CreER does not induce Cre activity in the DRN (Fig. S2). Compound TPH2-CreER/DAT-CreER/ Rosa26-LSL-tdTOMATO mice were used to identify 5-HTDRN innervated DA ${ }^{\text {VTA }}$ neurons, which account for $49 \%$ DA $^{\text {VTA }}$ cells [tdTOMATO $(+)$ ] (Fig. 2A-C). Using a CRACM approach under the voltage-clamp protocol, we detected eEPSC in $84 \%$ (16 out of 19) tested WGA $(+)$ tdTOMATO $(+)$ neurons evoked by blue light pulses (Fig. S4A-D), and detected elPSC in 15\% (4 out of 26) tested WGA $(+)$ tdTOMATO $(+)$ neurons (Fig. S4E-H).

Under a current-clamp mode, we found that blue light photostimulation caused rapid increases in firing frequency and resting membrane potential in all tested $5-\mathrm{HT}^{\mathrm{DRN}}$-innervated $\mathrm{DA} \mathrm{V}^{\mathrm{VTA}}$ neurons [WGA(+)tdTOMATO(+)] (Fig. 2D-F). Further, these activations were completely abolished by a selective $5-\mathrm{HT}_{2} \mathrm{C}$ antagonist, $100 \mu \mathrm{M}$ SB242084. These results indicate that stimulation of $5-\mathrm{HT}^{\mathrm{DRN}}$ neurons activates DA ${ }^{V T A}$ neurons via a $5-\mathrm{HT}_{2} \mathrm{R}$-mediated mechanism. Notably, unlike responses seen in $5-\mathrm{HT}^{\mathrm{DRN}}$-innervated POMC $\mathrm{ARH}^{\mathrm{A}}$ neurons (Fig. 1E, F), the baseline firing frequency and resting membrane potential of these 5-HT ${ }^{\text {RNN }}$-innervated DA ${ }^{\text {VTA }}$ neurons were not significantly altered by SB242084 (Fig. 2E, F), indicating that $5-\mathrm{HT}_{2} \mathrm{Rs}$ have minor tonic actions on these $D A^{V T A}$ neurons in a baseline condition.

We then examined the effects of $5-\mathrm{HT}^{\mathrm{DRN}} \rightarrow$ VTA circuit on both hunger-driven and non-hunger-driven feeding behaviors, using TPH2-CreER mice with ChR2-EYFP expressed in $5-\mathrm{HT}^{\mathrm{DRN}}$ neurons and the optic fiber implanted to target the VTA (Fig. $2 \mathrm{G}$ and Fig. S4I). In the hunger-driven feeding paradigm, photostimulation of the $5-\mathrm{HT}^{\mathrm{DRN}} \rightarrow$ VTA circuit by blue light pulses failed to significantly alter chow intake compared to the same mice 

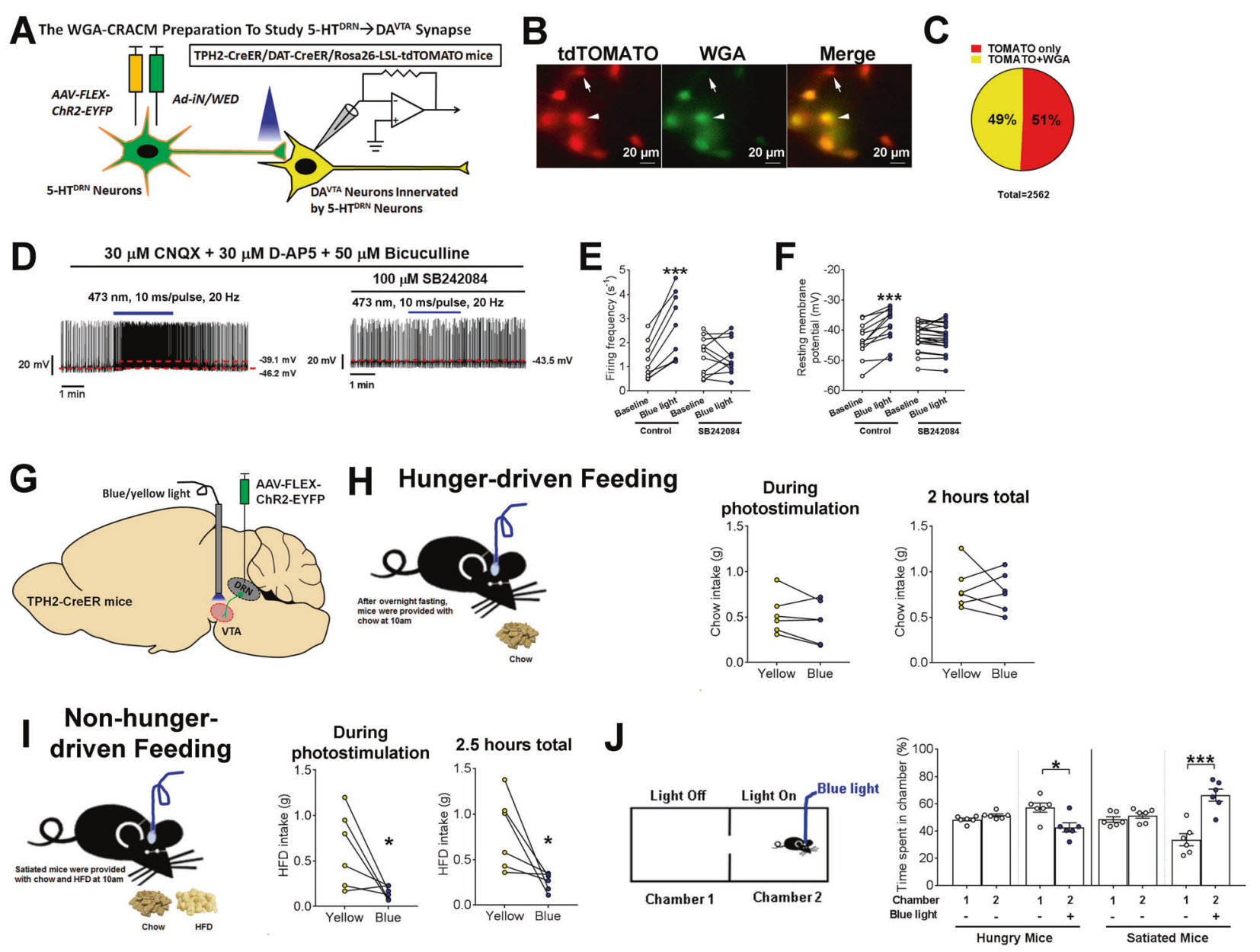

Fig. $25-\mathbf{H T}^{\mathrm{DRN}} \rightarrow$ VTA circuit inhibits non-hunger-driven feeding but not hunger-driven feeding. $\mathbf{A}$ Recordings in $5-\mathrm{HT}^{\mathrm{DRN}}$-innervated $\mathrm{DA}^{\text {VTA }}$ neurons [tdTOMATO(+)WGA(+)] in response to photostimulation of ChR2-labeled 5-HT ${ }^{\mathrm{DRN}}$-originated fibers within the VTA. B Representative images showing VTA neurons labeled by tdTOMATO, WGA, or both. Scale bars $=20 \mu \mathrm{m}$. The arrow points to a single-labeled neuron and the arrowhead points to a double-labeled neuron. $\mathbf{C}$ The composition of tdTOMATO-labeled DA ${ }^{\text {VTA }}$ neurons that are tdTOMATO (+) only and tdTOMATO(+)WGA(+). A total of $2562 \mathrm{DA}^{\mathrm{VTA}}$ neurons were counted from five mice. $\mathrm{D}$ Representative action potential traces in response to blue light pulses $(473 \mathrm{~nm}, 10 \mathrm{~ms} /$ pulse, $20 \mathrm{~Hz}$ ) in the absence or the presence of $100 \mu \mathrm{M}$ SB242084 in a bath solution containing $30 \mu \mathrm{M}$ CNQX, $30 \mu \mathrm{M}$ D-AP5, and $50 \mu \mathrm{M}$ bicuculline. E, F Firing frequency (E) and resting membrane potential (F) at the baseline or after blue light stimulation in the absence or the presence of $100 \mu \mathrm{M} \mathrm{SB242084}$. Results are shown as individual data points. ${ }^{* *} P<0.001$ between blue light vs. baseline in two-way ANOVA analyses followed by Sidak post hoc test ( $N=9-22$ neurons from three mice per group). $\mathbf{G}$ Schematic experimental strategy using optogenetics to activate the $5-\mathrm{HT}^{\mathrm{DRN}} \rightarrow$ VTA projections. $\mathbf{H}$ The experimental paradigm to measure hunger-driven feeding. Chow intake during photostimulation and during the total 2 -h period in mice with the $5-\mathrm{HT}^{\mathrm{DRN}} \rightarrow$ VTA projections unstimulated (yellow) or activated (blue). Results are shown as individual data points ( $N=6$ mice per group). I The experimental paradigm to measure nonhunger-driven feeding. HFD intake during photostimulation and during the total 2.5 -h period in mice with the $5-\mathrm{HT}^{\mathrm{DRN}} \rightarrow \mathrm{VTA}$ projections unstimulated (yellow) or activated (blue). Results are shown as individual data points. ${ }^{*} P<0.05$ between yellow vs. blue light in paired $t$ test ( $N$ $=6$ mice per group). $\mathbf{J}$ Left: the experimental paradigm to measure real-time place preference in mice with the 5 -HT ${ }^{\mathrm{DRN}} \rightarrow \mathrm{VTA}$ projections unstimulated when in chamber 1 and activated when in chamber 2; right: the \% time spent in each chamber in mice at hungry or satiated state with or without blue light stimulation coupled to chamber 2 . Results are shown as mean $\pm \mathrm{SEM}$ with individual data points. ${ }^{*} P<0.01$ and ${ }^{* * *} P<0.001$ in two-way ANOVA analyses followed by Sidak post hoc test ( $N=6$ mice per group).

receiving control yellow light stimulation (Fig. 2H). However, HFD intake during the non-hunger-driven feeding paradigm was significantly reduced by the photostimulation of the $5-\mathrm{HT}^{\mathrm{DRN}} \rightarrow$ VTA circuit, while chow intake was not affected (Fig. 21 and Fig. S4J). These data indicate that the stimulation of the $5-\mathrm{HT}^{\mathrm{DRN}} \rightarrow$ VTA circuit inhibits non-hunger-driven feeding, but has little effect on hunger-driven feeding. In the real-time place preference test, we observed that blue light photostimulation of the $5-\mathrm{HT}^{\mathrm{DRN}} \rightarrow$ VTA circuit induced a mild negative valance in hungry mice, but strikingly, the same photostimulation transmitted a strong positive valence in satiated mice (Fig. $2 \mathrm{~J}$ ).

\section{$5-\mathrm{HT}^{\mathrm{DRN}}$ neurons increase activity during hunger-driven feeding and non-hunger-driven feeding}

We then examined the dynamic changes of $5-\mathrm{HT}^{\mathrm{DRN}}$ neuron activity during hunger-driven feeding and non-hunger-driven feeding in vivo in real time. To this end, we stereotaxically injected AAV-FLEX-GCaMP6m into the DRN of TPH2-CreER mice 


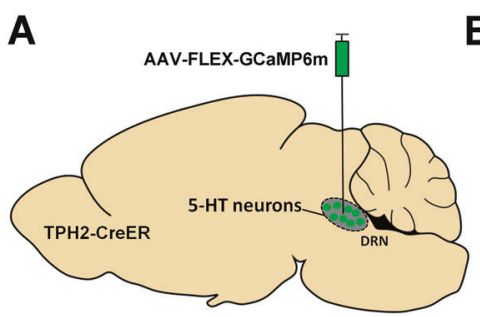

C 5-HT'DRN Neuron Activity

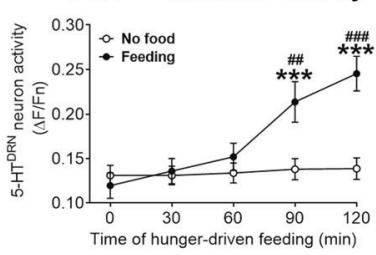

B Hunger-driven Feeding Intake Every $\mathbf{3 0}$ Munites

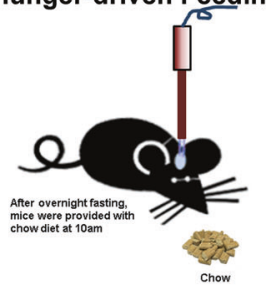

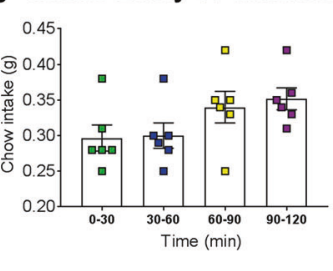

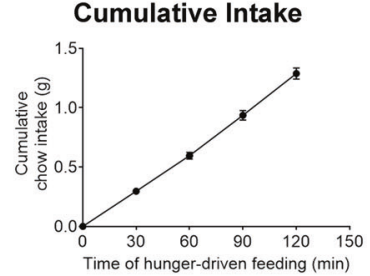

D Linear Regression

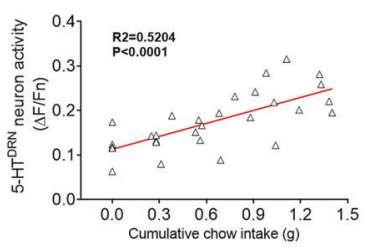

E Non-hunger-driven Feeding

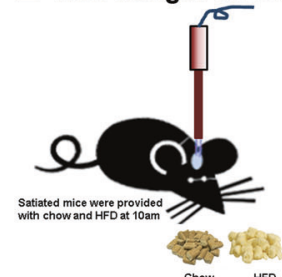

Intake Every $\mathbf{3 0}$ Munites

Cumulative Intake
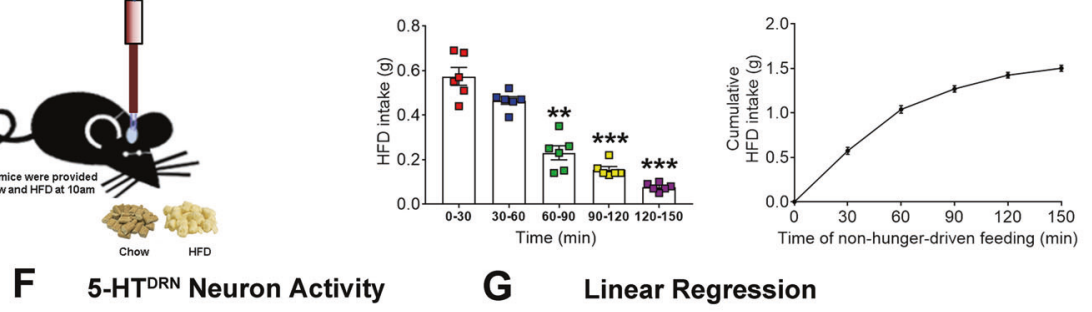

G

Linear Regression
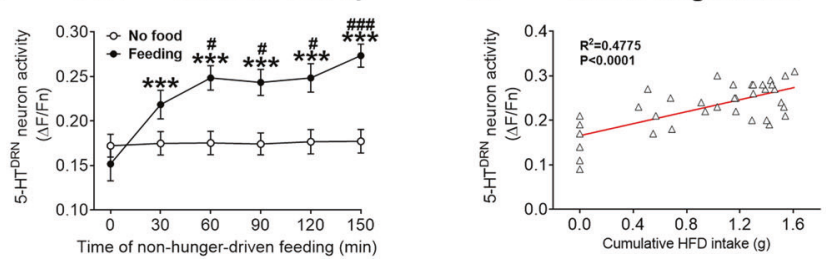

Fig. 3 Dynamics of 5-HT ${ }^{\mathrm{DRN}}$ neuron activity during hunger-driven feeding and non-hunger-driven feeding. A Schematic illustration to stereotaxically inject AAV-FLEX-GCaMP6m virus into the DRN of TPH2-CreER mice to express GCaMP6m in 5-HT ${ }^{\text {DRN }}$ neurons. B The schematic fiber photometry recordings of 5- $\mathrm{HT}^{\mathrm{DRN}}$ neuron activity in mice during the course of hunger-driven feeding (left), the amount of chow intake during each 30-min bin within the 2-h refeeding (middle), and the cumulative chow intake (right). Results are shown as mean \pm SEM with individual data points ( $N=6$ mice per group). $\mathrm{C} 5-\mathrm{HT}^{\mathrm{DRN}}$ neuron activity in mice during the course of 2-h hunger-driven feeding or in control hungry mice with no access to food. Results are shown as mean \pm SEM ( $N=5$ or 6 mice per group). ${ }^{* * *} P<0.001$ vs. time 0 ; \#\#P<0.01 and \#\#\#P $<0.001$ vs. no food group in two-way ANOVA analyses followed by Sidak post hoc test. $\mathbf{D}$ The linear regression curve of cumulative chow intake and $5-\mathrm{HT}^{\mathrm{DRN}}$ neuron activity during hunger-driven feeding. Results are shown as individual data points with the linear regression curve plotted. $\mathbf{E}$ The schematic fiber photometry recordings of $5-\mathrm{H} \mathrm{T}^{\mathrm{DRN}}$ neuron activity in mice during the course of non-hunger-driven feeding (left), the amount of HFD intake during each 30-min bin within 2.5-h feeding (middle), and the cumulative HFD intake (right). Results are shown as mean \pm SEM with individual data points $\left(N=6\right.$ mice per group). $F 5-\mathrm{HT}^{\mathrm{DRN}}$ neuron activity in mice during the course of $2.5-\mathrm{h}$ nonhunger-driven feeding. Results are shown as mean \pm SEM $\left(N=4\right.$ or 6 mice per group). ${ }^{* * *} P<0.001$ vs. time $0 ; \# P<0.05$ and \#\#\#P<0.001 vs. no food group in two-way ANOVA analyses followed by Sidak post hoc test. G The linear regression curve of cumulative HFD intake and 5-HT ${ }^{\mathrm{DRN}}$ neuron activity during non-hunger-driven feeding. Results are shown as individual data points with the linear regression curve plotted.

(with tamoxifen induction) to express the calcium sensor GCaMP6m selectively in 5-HTDRN neurons and implanted the optic fiber to target the DRN, which allowed in vivo monitoring of $5-\mathrm{HT}^{\mathrm{DRN}}$ neuron activity in functional mice (Fig. $3 \mathrm{~A}$ and Fig. $\mathrm{S} 5 \mathrm{~A})$. Mice were subjected to the hunger-driven feeding paradigm. Overnight fasted mice ate $0.25-0.35 \mathrm{~g}$ of chow every $30 \mathrm{~min}$, which resulted in a steady increase in cumulative chow intake during a 2-h refeeding period (Fig. 3B). Consistent with previous reports $[40,43]$, we observed rapid increases in $5-\mathrm{HT}^{\mathrm{DRN}}$ neuron activity that were tightly associated with onset of each eating bout and only lasted for a few seconds (Fig. S5B).
Interestingly, we noted that $5-\mathrm{HT}^{\mathrm{DRN}}$ neuron activity also displayed a slow, but constant elevation during the 2 -h feeding period (Fig. 3C). Linear regression analysis revealed a significant correlation between cumulative chow intake and $5-\mathrm{HT}^{\mathrm{DRN}}$ neuron activity (Fig. 3D).

We then subjected these mice to the non-hunger-driven feeding paradigm. Similarly, we observed transient elevations in $5-\mathrm{HT}^{\mathrm{DRN}}$ neuron activity associated with each eating bout (Fig. S5C). In addition, the 5-HT ${ }^{\mathrm{DRN}}$ neuron activity displayed a slow elevation, which was significantly correlated with the cumulative HFD consumption (Fig. 3E-G). Together, these results 
A

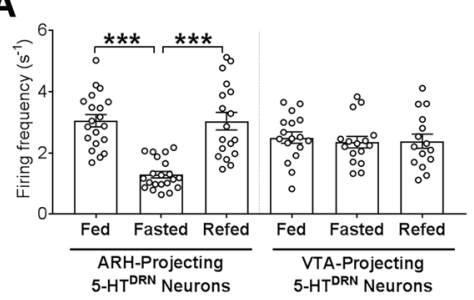

D ARH-projecting 5-HTDRN Neurons

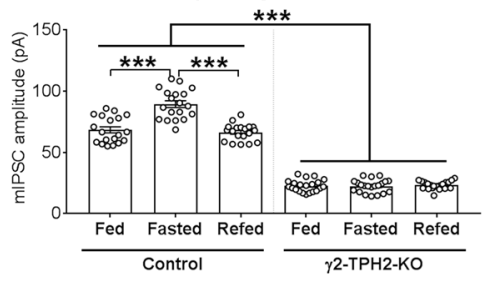

B

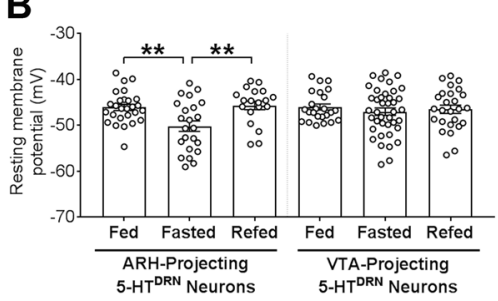

E

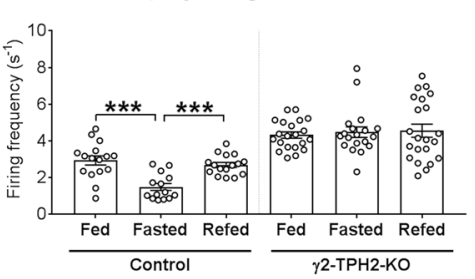

C

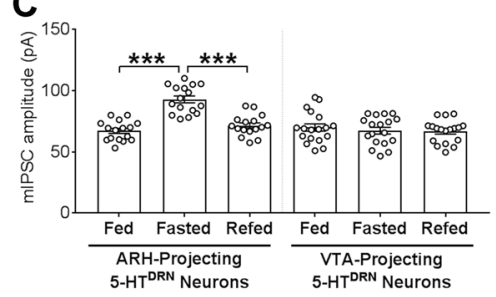

F

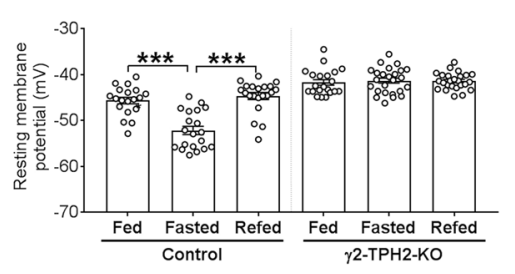

G

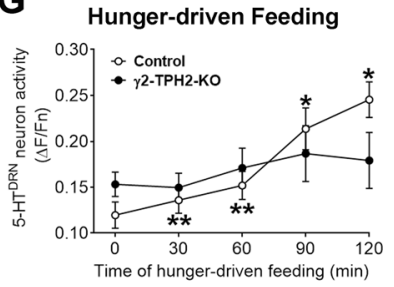

H

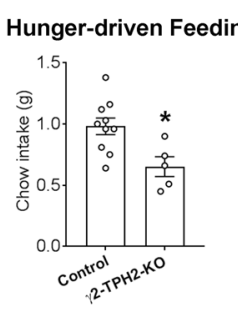

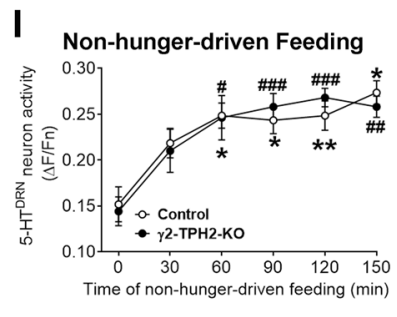

J

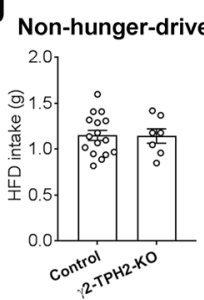

Fig. $4 \mathrm{GABA}_{\mathrm{A}}$ currents mediate dynamic changes in ARH-projecting 5-HT ${ }^{\mathrm{DRN}}$ neuron activity during hunger-driven feeding. A, B Firing frequency $(\mathbf{A})$ and resting membrane potential (B) in ARH-projecting or VTA-projecting 5-HTDRN neurons in mice fed ad libitum, fasted for overnight, or fasted for overnight followed by 2 -h refeeding. Results are shown as mean \pm SEM with individual data points. ${ }^{* *} P<0.01$ and ${ }^{* * *} P<0.001$ in one-way ANOVA analyses followed by Sidak post hoc test ( $N=15-27$ neurons from three mice per group). C Amplitude of mIPSC in ARH-projecting or VTA-projecting 5-HT DRN neurons in mice fed ad libitum, fasted for overnight, or fasted for overnight followed by 2 -h refeeding. Results are shown as mean \pm SEM with individual data points. ${ }^{* * *} P<0.001$ in one-way ANOVA analyses followed by Sidak post hoc test $(N=16-17$ neurons from three mice per group). D-F Amplitude of mIPSC (D), firing frequency (E), and resting membrane potential (F) in ARH-projecting 5-HT ${ }^{\mathrm{DRN}}$ neurons in control or $\gamma 2$-TPH2-KO mice fed ad libitum, fasted for overnight, or fasted for overnight followed by 2-h refeeding. Results are shown as mean \pm SEM with individual data points. ${ }^{* *} P<0.001$ in two-way ANOVA analyses followed by Sidak post hoc test $\left(N=14-25\right.$ neurons from three mice per group). G Averaged 5-HT $T^{\mathrm{DRN}}$ neuron activity in control or $\gamma 2-\mathrm{TPH} 2-\mathrm{KO}$ mice during the course of 2 -h hunger-driven feeding. Note that the data from control mice are the duplicate of data described in Fig. 3C. Results are shown as mean \pm SEM. ${ }^{*} P<0.05$ and ${ }^{* *} P<0.01$ vs. time 0 in control mice in two-way ANOVA analyses followed by Sidak post hoc test $(N=5$ or 6 mice per group). $\mathbf{H}$ The amount of chow intake during 2-h hunger-driven feeding in control or $\gamma 2-\mathrm{TPH} 2-\mathrm{KO}$ mice. Results are shown as mean \pm SEM with individual data points. ${ }^{*} P<0.05$ in $t$ test $\left(N=5\right.$ or 10 mice per group). I Averaged $5-\mathrm{HT}^{\mathrm{DRN}}$ neuron activity in control or $\gamma 2-\mathrm{TPH} 2-\mathrm{KO}$ mice during the course of 2.5-h non-hunger-driven feeding. Note that the data from control mice are the duplicate of data described in Fig. $3 \mathrm{~F}$. Results are shown as mean \pm SEM. ${ }^{*} P<0.05$ and ${ }^{*} P<0.01$ vs. time 0 in control mice; $\# P<0.05$, \#\#P<0.01, and \#\#\#P<0.001 vs. time 0 in $\gamma 2$ TPH2-KO mice in two-way ANOVA analyses followed by Sidak post hoc test ( $N=5$ or 6 mice per group). $J$ The amount of HFD intake during 2.5 -h non-hunger-driven feeding in control or $\gamma 2-\mathrm{TPH} 2-\mathrm{KO}$ mice. Results are shown as mean \pm SEM with individual data points $(N=7$ or 16 mice per group).

indicate that during both hunger-driven and non-hunger-driven feeding, 5-HT ${ }^{\mathrm{DRN}}$ neuron activity gradually escalates in the scale of minutes and hours, which is correlated with the amount of food consumed.

GABA $_{A}$ currents mediate dynamic changes in ARH-projecting 5-HT ${ }^{\mathrm{R} N}$ neuron activity during hunger-driven feeding

We next explored whether the activity of 5-HT $\mathrm{T}^{\mathrm{DN}}$ neurons projecting to the ARH and/or VTA changes in association with hunger-driven feeding. To this end, TPH2-CreER/Rosa26-LSLtdTOMATO mice were stereotaxically injected with green and purple RetroBeads into the ARH and VTA, respectively (Fig. S6A). Brain slices containing the DRN were freshly prepared from mice fed ad libitum, overnight fasted, or overnight fasted followed by 2$h$ refeeding. Electrophysiological recordings were performed in tdTOMATO-labeled 5-HT DRN neurons projecting to the ARH (colabeled by green beads) or in tdTOMATO-labeled 5-HT ${ }^{\mathrm{DRN}}$ neurons projecting to the VTA (co-labeled by purple beads, Fig. S6A). The firing frequency and resting membrane potential of
ARH-projecting $5-\mathrm{HT}^{\mathrm{DRN}}$ neurons in fasted mice were significantly reduced compared to fed mice, and 2 -h refeeding increased firing frequency and resting membrane potential to the level of fed mice (Fig. 4A, B). On the other hand, firing frequency and resting membrane potential of VTA-projecting $5-\mathrm{HT}^{\mathrm{DRN}}$ neurons were not affected by these conditions (Fig. 4A, B).

To further explore the mechanisms for the dynamic $5-\mathrm{HT}^{\mathrm{DRN}}$ neuron activity during the hunger-driven feeding, we examined the mEPSC and the SK currents in ARH- and VTA-projecting 5$\mathrm{HT}^{\mathrm{DRN}}$ neurons, and did not observe any significant changes in these currents in the different feeding conditions (Fig. S6B-D). However, the amplitude of miniature IPSC (mIPSC) in $\mathrm{ARH}$ projecting $5-\mathrm{HT}^{\mathrm{DRN}}$ neurons was significantly enhanced by fasting compared to fed mice, and 2 -h refeeding largely restored mIPSC amplitude to the level of fed mice. mIPSC amplitude in VTAprojecting $5-\mathrm{HT}^{\mathrm{DRN}}$ neurons was not affected (Fig. 4C). No differences were observed in the frequency of mIPSC by feeding conditions (Fig. S6E). Given the inhibitory nature of MIPSC, we hypothesized that GABA-mediated mIPSC contributes to the 
A

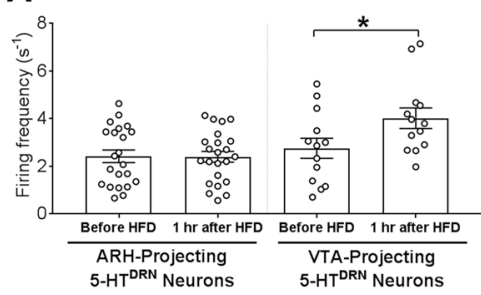

B

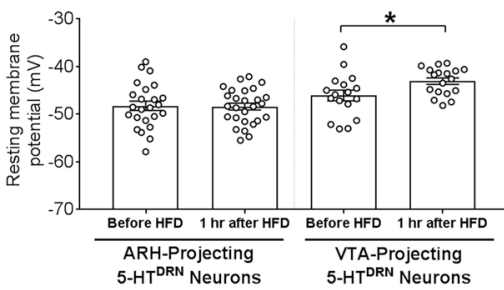

C

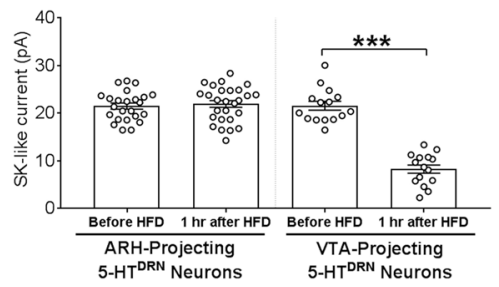

D VTA-Projecting 5-HT DRN Neurons

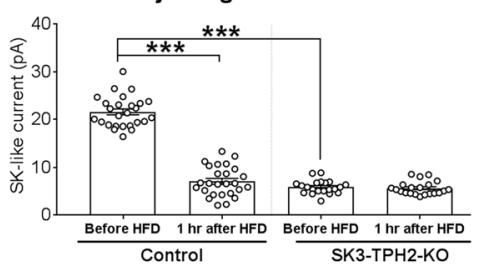

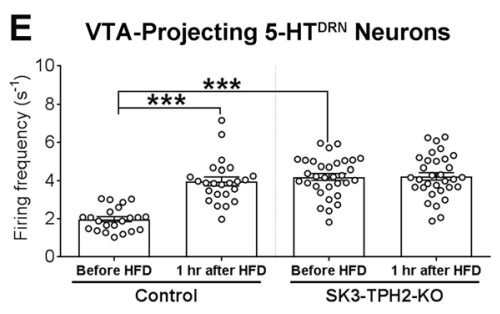

F VTA-Projecting 5-HT ${ }^{\text {DRN }}$ Neurons

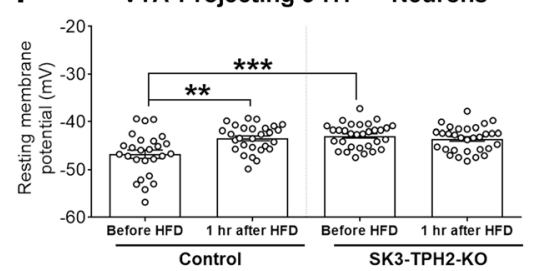

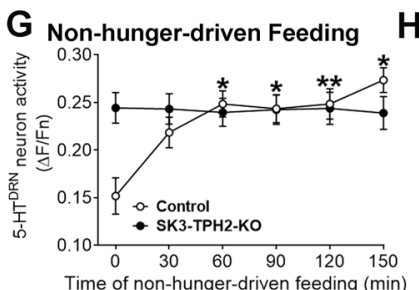

H Non-hunger-driven Feeding I

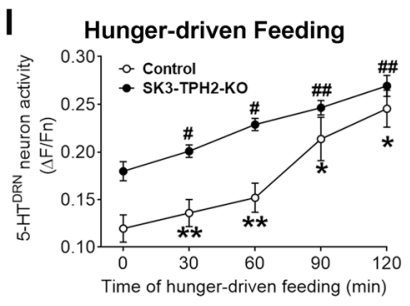

$\mathbf{J}$ Hunger-driven Feeding
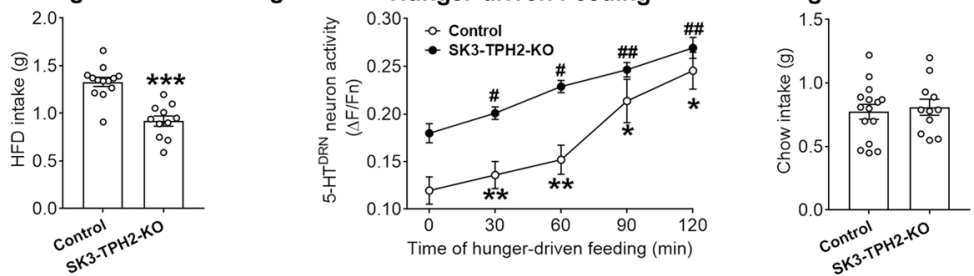

Fig. 5 SK currents mediate dynamic changes in VTA-projecting 5-HT ${ }^{\mathrm{DRN}}$ neuron activity during non-hunger-driven feeding. A, B Firing frequency (A) and resting membrane potential (B) in ARH-projecting or VTA-projecting 5-HT ${ }^{\mathrm{DNN}}$ neurons in mice before and 1-h after nonhunger-driven feeding. Results are shown as mean \pm SEM with individual data points. ${ }^{*} P<0.05$ in $t$ test $(N=13-27$ neurons from three mice per group). C Amplitude of SK-like currents in ARH-projecting or VTA-projecting 5-HTDRN neurons in mice before and 1-h after non-hungerdriven feeding. Results are shown as mean \pm SEM with individual data points. ${ }^{* * *} P<0.001$ in $t$ test $(N=14-27$ neurons from three mice per group). D-F Amplitude of SK-like currents (D), firing frequency (E), and resting membrane potential (F) in VTA-projecting 5-HT ${ }^{\text {RNN }}$ neurons in control or SK3-TPH2-KO mice before and 1-h after non-hunger-driven feeding. Results are shown as mean \pm SEM with individual data points. ${ }^{* *} P<0.01$ and ${ }^{* * *} P<0.001$ in two-way ANOVA analyses followed by Sidak post hoc test $(N=21-32$ neurons from three mice per group). G Averaged 5-HT ${ }^{\mathrm{DRN}}$ neuron activity in control or SK3-TPH2-KO mice during the course of 2.5-h non-hunger-driven feeding. Note that the data from control mice are the duplicate of data described in Fig. 3F. Results are shown as mean \pm SEM. ${ }^{*} P<0.05$ and ${ }^{* *} P<0.01$ vs. time 0 in control mice in two-way ANOVA analyses followed by Sidak post hoc test ( $N=5$ or 7 mice per group). $\mathbf{H}$ The amount of HFD intake during 2.5 -h nonhunger-driven feeding in control or SK3-TPH2-KO mice. Results are shown as mean \pm SEM with individual data points. ${ }^{* * *} P<0.001$ in $t$ test $(N$ $=11$ or 13 mice per group). I Averaged $5-\mathrm{HT}^{\mathrm{DRN}}$ neuron activity in control or SK3-TPH2-KO mice during the course of 2 -h hunger-driven feeding. Note that the data from control mice are the duplicate of data described in Fig. 3C. Results are shown as mean \pm SEM. ${ }^{*} P<0.05$ and ${ }^{* *} P<0.01$ vs. time 0 in control mice; $\# P<0.05$ and \#\#P<0.01 vs. time 0 in SK3-TPH2-KO mice in two-way ANOVA analyses followed by Sidak post hoc test $(N=5$ or 6 mice per group). J The amount of chow intake during 2-h hunger-driven feeding in control or SK3-TPH2-KO mice. Results are shown as mean \pm SEM with individual data points $(N=11$ or 15 mice per group).

dynamic ARH-projecting $5-\mathrm{HT}^{\mathrm{DRN}}$ neuron activity during the course of hunger-driven feeding.

To examine this, we generated $\gamma 2-\mathrm{TPH} 2-\mathrm{KO}$ mice which lack the pore-forming $\gamma 2$ subunit of $\mathrm{GABA}_{\mathrm{A}}$ receptor $[31,50,51]$ specifically in 5-HT neurons and their control littermates (Fig. S6F). We found that mIPSC amplitude, but not frequency, in ARH-projecting 5-HT DRN neurons from $\mathrm{Y2}$-TPH2-KO mice was significantly smaller than control mice, and the dynamic pattern of mIPSC we observed in control mice during the hunger-driven feeding was abolished in $\mathrm{Y2}-\mathrm{TPH} 2-\mathrm{KO}$ mice (Fig. 4D and Fig. $\mathrm{S} 6 \mathrm{G})$. Importantly, the firing frequency and resting membrane potential of ARH-projecting 5-HT ${ }^{\mathrm{RNN}}$ neurons from $\mathrm{Y2}-\mathrm{TPH} 2-\mathrm{KO}$ mice did not display the dynamic alterations during the course of hunger-driven feeding, as seen in those from control mice (Fig. 4E, F). Consistently, fiber photometry demonstrated that 5$\mathrm{HT}^{\mathrm{DRN}}$ neuron activity in $\mathrm{\gamma} 2-\mathrm{TPH} 2-\mathrm{KO}$ mice was not gradually regulated during the course of hunger-driven feeding (Fig. 4G), although the transient elevations associated with onset of eating bouts were still observed (Fig. S6H) similarly as those in control mice (Fig. S5B). Importantly, in the hunger-driven feeding paradigm, the amount of chow intake during the 2-h refeeding period was significantly reduced compared to control mice (Fig. 4H). However, during non-hunger-driven feeding, 5$\mathrm{HT}^{\mathrm{DRN}}$ neuron activity in $\mathrm{Y2}-\mathrm{TPH} 2-\mathrm{KO}$ mice displayed similar elevations and HFD and chow intake were comparable to control mice (Fig. 4I, J, S6I). Together, these results indicate that $\mathrm{GABA}_{A}$ currents mediate dynamic changes in ARH-projecting 5$\mathrm{HT}^{\mathrm{DRN}}$ neuron activity during hunger-driven feeding.

\section{SK currents mediate dynamic changes in VTA-projecting 5-} $\mathrm{HT}^{\mathrm{DRN}}$ neuron activity during non-hunger-driven feeding

We also examined the ex vivo dynamic firing activities of $\mathrm{ARH}$ and/or VTA-projecting 5-HT ${ }^{\mathrm{DRN}}$ neurons during the course of nonhunger-driven feeding (Fig. S6A). Firing frequency and resting membrane potential of VTA-projecting 5-HT DRN neurons were significantly increased $1 \mathrm{~h}$ after non-hunger-driven feeding compared to the baseline levels, whereas the activity of $\mathrm{ARH}$ projecting $5-\mathrm{HT}^{\mathrm{DRN}}$ neurons did not change (Fig. 5A, B). We did not detect any significant changes in mIPSC or mEPSC in these neurons (Fig. S7A-D). Interestingly, SK currents in VTA-projecting 
$5-\mathrm{HT}^{\mathrm{DRN}}$ neurons, but not in ARH-projecting neurons, were significantly reduced $1 \mathrm{~h}$ after non-hunger-driven feeding (Fig. $5 \mathrm{C}$ ).

To examine the physiological role of SK currents in $5-\mathrm{HT}^{\mathrm{DRN}}$ neurons in feeding control, we generated control littermates and SK3-TPH2-KO mice with 5-HT-specific deletion of SK3 (Fig. S7E), the most abundant SK isoform in the DRN [52]. SK currents in VTAprojecting $5-\mathrm{HT}^{\mathrm{DRN}}$ neurons from SK3-TPH2-KO mice were significantly smaller than control mice, and the dynamic pattern of SK currents we observed in control mice during non-hungerdriven feeding was abolished in SK3-TPH2-KO mice (Fig. 5D). Importantly, the firing frequency and resting membrane potential of VTA-projecting 5-HT ${ }^{\mathrm{DRN}}$ neurons from SK3-TPH2-KO mice were significantly elevated, and they did not display the dynamic alterations during the course of non-hunger-driven feeding as seen in those from control mice (Fig. 5E, F). Consistently, we used fiber photometry to demonstrate that unlike control mice, the $5-\mathrm{HT}^{\mathrm{DRN}}$ neuron activity in SK3-TPH2-KO mice did not alter during the course of non-hunger-driven feeding (Fig. 5G), although the transient elevations associated with onset of eating bouts were still observed (Fig. S7F). Importantly, the amount of HFD intake, but not chow intake, during the non-hunger-driven feeding paradigm was significantly reduced compared to control mice (Fig. 5H and Fig. S7G). Interestingly, during hunger-driven feeding, the $5-\mathrm{HT}^{\mathrm{DRN}}$ neuron activity in SK3-TPH2-KO mice, although starting from a higher baseline level, displayed similar elevations as in control mice, and their refeeding behavior was comparable (Fig. 5I, J). Together, these results indicate that SK currents mediate dynamic changes in VTA-projecting $5-\mathrm{HT}^{\mathrm{DRN}}$ neuron activity during non-hunger-driven feeding. We then subjected control and SK3-TPH2-KO mice to the open-field test, the light-dark test, the elevated plus maze test, and forced swim test, and found comparable locomotor activity, anxiety-like, and depression-like behaviors in these mice (Fig. S8). Thus, we suggest that the reduced non-hunger-driven feeding in these mice was not secondary to changes in animals' locomotion and mood. Finally, we compared SK3 protein levels in the DRN before and after mice conducted non-hunger-driven feeding, and found that 2.5-h non-hunger-driven feeding significantly reduced SK3 levels in the DRN (Fig. S9).

\section{DISCUSSIONS}

The primary cause of the global obesity epidemic is the overconsumption of food, which is driven by hungerdependent and -independent mechanisms. Here, we aimed to define specific brain circuits modulating hunger-driven and nonhunger-driven feeding behavior with the objective of informing the rational design of precision medicines for the treatment of obesity. We employed a commonly used paradigm [37, 53, 54] to measure hunger-driven feeding as a rapid chow refeeding behavior induced by overnight fasting. Non-hunger-driven feeding was assessed as HFD intake in satiated mice presented with a free choice of HFD and chow diet; importantly, we only measured HFD intake for $2.5 \mathrm{~h}$ during the morning, instead of a longer period (e.g., 12 and $24 \mathrm{~h}$ ) or during the late afternoon/ evening, which should minimize food intake triggered by hunger or circadian cues. Of course, one limitation is that we did not measure food intake in longer periods and may have missed potential rebound in feeding. Nevertheless, using these feeding paradigms, we provide the insight into the in vivo activity of $5-\mathrm{HT}^{\mathrm{DRN}}$ neurons in response to different types of foods and reveal that $5-\mathrm{HT}^{\mathrm{DRN}}$ neurons progressively increase their activity during food consumption. Further, we report that activation of the $5-\mathrm{HT}^{\mathrm{DRN}} \rightarrow \mathrm{ARH}$ projections efficiently decreased hunger-driven feeding, but had no effect on nonhunger-driven feeding, whereas activation of the $5-\mathrm{HT}^{\mathrm{DRN}} \rightarrow$ VTA projections robustly inhibited non-hunger-driven feeding, but had no effect on hunger-driven feeding.
The ARH was first demonstrated to be a necessary homeostatic feeding center through lesion studies in last century, and the past few decades have revealed the importance of POMC ${ }^{\mathrm{ARH}}$ and $\mathrm{AgRP}^{\mathrm{ARH}}$ neurons in mediating this effect $[55,56]$. We and others have reported that $5-\mathrm{HT}$, like other hormones and neurotransmitters, regulates the activity of POMC ${ }^{\mathrm{ARH}}$ and $\mathrm{AgRP}^{\mathrm{ARH}}$ neurons [57-59]. However, the source of 5-HT sufficient to modulate the POMC $^{A R H}$ and AgRPARH activity, and feeding behavior has not been fully clarified. Here, we report that $5-\mathrm{HT}^{\mathrm{DRN}}$ neurons innervate around half of anorexigenic POMC ${ }^{\mathrm{ARH}}$ cells via 5$\mathrm{HT}_{2} \mathrm{C}$ Rs and a subset of orexigenic AgRP ${ }^{\mathrm{ARH}}$ neurons via $5-\mathrm{HT}_{1 \mathrm{~B}} \mathrm{Rs}$. We report that all $5-\mathrm{HT}^{\mathrm{DRN}}$-innervated $\mathrm{POMC}^{\mathrm{ARH}}$ neurons were activated by $5-\mathrm{HT}_{2} \mathrm{R}$-mediated 5 -HTergic inputs. Notably, since these current-clamp recordings were performed in the presence of GABA and glutamate receptor inhibitors to block the majority of fast synaptic inputs, we suggest that the observed rapid activations in tested neurons likely reflect responses to direct synaptic inputs from 5-HT ${ }^{\mathrm{DRN}}$ neurons. It is striking that in the presence of GABA and glutamate receptor inhibitors, the $5-\mathrm{HT}_{2} \mathrm{C}$ antagonist (SB242084) completely abolished the spontaneous firing of $5-\mathrm{HT}^{\mathrm{DRN}}$-innervated $\mathrm{POMC} \mathrm{C}^{\mathrm{ARH}}$ neurons. Thus, we suggest that the $5-\mathrm{HT}$ inputs (acting through $5-\mathrm{HT}_{2} \mathrm{Rs}$ ) and glutamatergic inputs provide the majority of excitatory drive to this subset of POMC ${ }^{A R H}$ neurons. These findings are consistent with earlier reports that $5-\mathrm{HT}_{2} \mathrm{R}$ agonists activate a portion of POMC ${ }^{\mathrm{ARH}}$ neurons $[14,58]$. Further, deletion of $5-\mathrm{HT}_{2 \mathrm{C}} \mathrm{Rs}$ from POMC neurons leads to hyperphagia and obesity in mice [26] and 5$\mathrm{HT}_{2} \mathrm{C}$ Rs expressed by POMC neurons partly mediates anorexigenic effects of 5-HT analogs during hunger-driven feeding [60]. We also observed that all $5-\mathrm{HT}^{\mathrm{DRN}}$-innervated $\mathrm{AgRP}^{\mathrm{ARH}}$ neurons were inhibited by $5-\mathrm{HT}_{1 \mathrm{~B}} \mathrm{R}$-mediated 5 -HTergic inputs. These results are consistent with previous reports that $5-\mathrm{HT}_{1 \mathrm{~B}} \mathrm{Rs}$ inhibit AgRP $\mathrm{ARH}^{\mathrm{A}}$ neurons and $5-\mathrm{HT}_{1 \mathrm{~B}} \mathrm{R}$ agonists reduce hunger-driven feeding [57]. Together, these observations indicate that a subset of $5-\mathrm{HT}^{\mathrm{DRN}}$ neurons project to the $A R H$, where they activate POMC ${ }^{A R H}$ neurons via $5-\mathrm{HT}_{2} \mathrm{C}$ Rs and inhibit AgRP ${ }^{\mathrm{ARH}}$ neurons via $5-\mathrm{HT}_{1 \mathrm{~B}} \mathrm{Rs}$ to reduce hunger-driven feeding. Such findings suggest that in addition to the $5-\mathrm{HT}_{2} \mathrm{C}$, the $5-\mathrm{HT}_{1 \mathrm{~B}} \mathrm{R}$ may be another suitable target for the treatment of obesity. Indeed, coadministration of $5-\mathrm{HT}_{2} \mathrm{C}$ and $5-\mathrm{HT}_{1 \mathrm{~B}} \mathrm{R}$ agonists in animals produces a greater reduction in food intake compared to single agonist treatment [61].

A separate population of $5-\mathrm{HT}^{\mathrm{DRN}}$ neurons innervate a subset of $D^{\text {VTA }}$ neurons. DA ${ }^{\text {VTA }}$ neurons are instrumental in modulating motivation and reward-related behaviors. We report that $5-\mathrm{HT}^{\mathrm{DRN}}$ influences the activity of DA VTA neurons, and this effect is mediated via the $5-\mathrm{HT}_{2} \mathrm{C}$ Rs. In line with this finding, we previously reported that lorcaserin activates $\mathrm{DA}^{\mathrm{VTA}}$ neurons, effects that are blocked by deletion of $5-\mathrm{HT}_{2} \mathrm{Rs}$ in $\mathrm{DA}$ neurons [15]. Further, deletion of $5-\mathrm{HT}_{2} \mathrm{Rs}$ in DA neurons blocks effects of lorcaserin to inhibit binge-like eating (a feeding behavior largely driven by hedonic value of high palatable food), but not hunger-driven feeding [15]. Together, these results indicate that a subset of 5$\mathrm{HT}^{\mathrm{DRN}}$ neurons project to and activate $\mathrm{DA}{ }^{\mathrm{VTA}}$ neurons via $5-\mathrm{HT}_{2} \mathrm{C}$ mediated mechanisms, which inhibits non-hunger-driven feeding. In addition to the VTA and $\mathrm{ARH}, 5-\mathrm{HT}_{2} \mathrm{CRs}$ are also expressed in other brain regions, e.g., the lateral hypothalamic area and the ventral hippocampus [62], both of which are involved in feeding control [63-65]. The potential role of $5-\mathrm{HT}_{2} \mathrm{CRs}$ in these brain regions warrant future investigations.

Notably, a small portion of $5-\mathrm{HT}^{\mathrm{DRN}}$ neurons do have collateral projections to both the ARH and VTA, which may confound the circuit-specific stimulation. Nevertheless, given the drastic differences in the phenotypic outcome associated with the photostimulation of these two projections, we suggest that these collaterals likely play a minor role in our experimental settings. Thus, our findings are in line with the notion that neural circuits regulating hunger-driven feeding vs. non-hunger-driven feeding 
are segregated. Consistently, while animals without AgRPARH neurons can appropriately consume high palatable food [66], these neurons are dispensable for normal feeding responses induced by hunger signals, e.g., ghrelin [66] and asprosin [67]. However, it has to be pointed out that these two feedingregulatory systems can interplay with each other. For instance, ghrelin can enhance the responses of DA ${ }^{\mathrm{VTA}}$ neurons to hedonic cues [68], whereas chronic HFD feeding reduces the responses of $\mathrm{AgRP}^{\mathrm{ARH}}$ neurons to ghrelin [35]. Indeed, $\mathrm{DA}^{\mathrm{VTA}}$ neurons are reported to receive indirect inputs from $\mathrm{AgRP}^{\mathrm{ARH}}$ neurons [35] and POMC $^{\text {ARH }}$ neurons [33], which may provide anatomical basis for the crosstalk between the homeostatic and the hedonic circuitry.

In addition to 5-HT-mediated neurotransmissions, we also noted that $5-\mathrm{HT}^{\mathrm{DRN}}$ neurons provide glutamatergic or GABAergic inputs to a portion (but not all) of innervated neurons. This is consistent with recent findings that $5-\mathrm{HT}^{\mathrm{DRN}}$ neurons are partially overlapping with glutamatergic or GABAergic neurons [43, 44]. Notably, hunger-driven feeding can be inhibited by selective stimulation of glutamatergic neurons in the DRN or by inhibition of GABAergic neurons in the DRN [69]. We found that in the presence of glutamate and GABA receptor inhibitors, $5-\mathrm{HT}^{\mathrm{DRN}}$ neurons can provide 5-HTergic inputs to all tested ARH neurons in the in vitro preparation. However, we cannot fully rule out the in vivo contribution of glutamatergic and/or GABAergic outputs from $5-\mathrm{HT}^{\mathrm{DRN}}$ neurons to the regulation of hunger-driven feeding, as well as non-hunger-driven feeding. Future studies are warranted to further dissect out the contributions of 5-HT signaling, vs. glutamate or GABA co-released by $5-\mathrm{HT}^{\mathrm{DRN}}$ neurons, to the regulation of feeding behavior.

It has been reported that $5-\mathrm{HT}^{\mathrm{DRN}}$ neurons can be transiently (on a time scale of seconds) activated by various stimuli, e.g., sex, social interaction, sucrose, or food pellet intake $[40,43]$. Consistently, we observed transient activations of $5-\mathrm{HT}^{\mathrm{DRN}}$ neurons associated with onset of eating bouts (either chow or HFD). However, we found that these eating bout-associated transient elevations in 5-HT ${ }^{\mathrm{DNN}}$ neurons persisted in $\mathrm{Y} 2-\mathrm{TPH} 2-\mathrm{KO}$ and SK3-TPH2-KO mice. Given these mutant mouse models displayed altered hunger-driven or non-hunger-driven feeding, we suggest that the transient elevations in $5-\mathrm{HT}^{\mathrm{DRN}}$ neurons do not have regulatory effects on feeding behavior per se, although they may encode certain aspects of eating, e.g., initiation of an eating bout or detection of food. On the other hand, we found that 5-HTDRN neurons also chronically increased their activities during the course of feeding on a time scale of minutes to hours. Considering that activation of $5-\mathrm{HT}^{\mathrm{DRN}}$ neurons inhibits feeding, we suggest that $5-\mathrm{HT}^{\mathrm{DRN}}$ neurons function as a key component of a negative feedback loop. Thus, feeding, either driven by hunger or by hunger-independent cues, gradually activates $5-\mathrm{HT}^{\mathrm{DRN}}$ neurons, and this slowly elevated $5-\mathrm{HT}^{\mathrm{DRN}}$ neuron activity then terminates the meal to prevent overeating. Notably, meal termination can be regulated by other neural populations, including calcitonin gene-related peptide-expressing neurons in the external lateral parabrachial nucleus [70] and catecholamine neurons in the nucleus of solitary tract [71]. It remains unclear whether these neural nodes, including $5-\mathrm{HT}^{\mathrm{DRN}}$ neurons, function in a parallel fashion, or within an interconnected network to regulate meal termination.

The slow dynamic changes in $5-\mathrm{HT}^{\mathrm{DRN}}$ neurons are not associated with presynaptic alternations (e.g., changes in frequencies of mEPSC and mIPSC), which could happen in seconds. Rather, distinct postsynaptic mechanisms are involved in the regulations of $5-\mathrm{HT}^{\mathrm{DRN}}$ neuron activity during hunger-driven vs. non-hunger-driven feeding. On one hand, hunger-driven feeding increased ARH-projecting 5-HT DRN neuron activity by reducing the amplitude of mIPSC. On the other hand, non-hunger-driven feeding activated VTA-projecting $5-\mathrm{HT}^{\mathrm{DRN}}$ neurons by reducing a SK outward potassium current. It is worth noting that comparable mIPSCs were detected in ARH- and VTA-projecting $5-\mathrm{HT}^{\mathrm{DRN}}$ neurons, although only the mIPSC in the former subset was regulated by hunger-driven feeding. Similarly, comparable SK currents were detected in ARH- and VTA-projecting 5-HT ${ }^{\mathrm{DRN}}$ neurons, although only the SK current in the latter subset was regulated by non-hunger-driven feeding. Thus, while both these currents exist in the two subsets of $5-\mathrm{HT}^{\mathrm{DRN}}$ neurons, their responses to hunger-driven feeding and non-hunger-driven feeding may involve different regulatory mechanisms which remain unclear. Since $5-\mathrm{HT}^{\mathrm{DRN}}$ neuron activity was correlated with the amount of chow or HFD intake, we speculate that the consumed nutrients, calories, and/or the nutritional state of the animal may contribute to the slow dynamic changes in $5-\mathrm{HT}^{\mathrm{DRN}}$ neurons, although such possibilities need to be further validated. In addition, our observations that non-hunger-driven feeding can reduce SK3 protein levels in the DRN suggest that carbohydrates and/or lipids in the diets may regulate levels of ion channels, and therefore influence neural activity.

It is worth mentioning that the role of $5-\mathrm{HT}^{\mathrm{DRN}}$ neurons in the reward-related behaviors are complex. Correia et al. reported no place preference or aversion associated with repetitive placecontingent pairing of optogenetic activation of $5-\mathrm{HT}^{\mathrm{DRN}}$ neurons [72]. However, multiple groups demonstrated that optogenetic activation of $5-\mathrm{HT}^{\mathrm{DRN}}$ neurons or the $5-\mathrm{HT}^{\mathrm{DRN}} \rightarrow$ VTA projections increase place preference and other reward-related behaviors $[73,74]$. Consistent with the latter, here we found that activation of the $5-\mathrm{HT}^{\mathrm{DRN}} \rightarrow \mathrm{VTA}$ projections increased place preference in satiated mice, which was, however, totally reversed in hungry mice. On the other hand, activation of the $5-\mathrm{HT}^{\mathrm{DRN}} \rightarrow \mathrm{ARH}$ projections increased place preference only in hungry mice, but not in satiated mice. Thus, our results add to this complexity and suggest that $5-\mathrm{HT}^{\mathrm{DRN}}$ neurons play different roles in regulating place preference depending on the different downstream neural circuits and on the nutritional states of animals. Similarly, a circuit from the paraventricular hypothalamus to the lateral parabrachial nucleus has been reported to increase place preference only in hungry mice, an effect that is completely blocked in satiated mice [75].

Owing to the diverse etiologies of obesity, it has been difficult to treat with medication and is therefore ideally suited to a precision medication approach. Here, we investigated specific brain regions underpinning different types of feeding behaviors. We report that hunger-driven and non-hunger-driven feeding can gradually activate $5-\mathrm{HT}^{\mathrm{DRN}}$ neurons, via either inhibiting responsiveness to inhibitory GABAergic inputs or by reducing a potassium outward current. Activated $5-\mathrm{HT}^{\mathrm{DRN}}$ neurons in turn inhibit hunger-driven and non-hunger-driven feeding through their projections to the ARH and VTA, respectively. These $5-\mathrm{HT}^{\mathrm{DRN}}$ originated neural circuits constitute a negative feedback loop to trigger the end of a meal. These findings suggest that individuals with increased hunger could benefit from a medication targeting the $5-\mathrm{HT}^{\mathrm{DRN}} \rightarrow \mathrm{ARH}$ circuit, individuals who overeat in the absence of hunger could benefit from a medication targeting the $5-\mathrm{HT}^{\mathrm{DRN}} \rightarrow$ VTA circuit.

\section{REFERENCES}

1. Alonso-Alonso M, Woods SC, Pelchat M, Grigson PS, Stice E, Farooqi S, et al. Food reward system: current perspectives and future research needs. Nutr Rev. 2015;73:296-307.

2. Kenny PJ. Reward mechanisms in obesity: new insights and future directions. Neuron. 2011;69:664-79.

3. Lechin F, van der Dijs B, Hernandez-Adrian G. Dorsal raphe vs. median raphe serotonergic antagonism. Anatomical, physiological, behavioral, neuroendocrinological, neuropharmacological and clinical evidences: relevance for neuropharmacological therapy. Prog Neuropsychopharmacol Biol Psychiatry. 2006;30:565-85.

4. De Fanti BA, Hamilton JS, Horwitz BA. Meal-induced changes in extracellular 5-HT in medial hypothalamus of lean $(\mathrm{Fa} / \mathrm{Fa})$ and obese $(\mathrm{fa} / \mathrm{fa})$ Zucker rats. Brain Res. 2001;902:164-70. 
5. Rowland NE, Carlton J. Neurobiology of an anorectic drug: fenfluramine. Prog Neurobiol. 1986;27:13-62.

6. Foltin RW, Moran TH. Food intake in baboons: effects of a long-acting cholecystokinin analog. Appetite. 1989;12:145-52.

7. McGuirk J, Goodall E, Silverstone T, Willner P. Differential effects of d-fenfluramine, l-fenfluramine and d-amphetamine on the microstructure of human eating behaviour. Behav Pharm. 1991;2:113-9.

8. Rogers PJ, Blundell JE. Effect of anorexic drugs on food intake and the micro-structure of eating in human subjects. Psychopharmacology. 1979;66:159-65.

9. Blundell JE, Leshem MB. Central action of anorexic agents: effects of amphetamine and fenfluramine in rats with lateral hypothalamic lesions. Eur J Pharm. 1974;28:81-8.

10. Geyer MA, Puerto A, Menkes DB, Segal DS, Mandell AJ. Behavioral studies following lesions of the mesolimbic and mesostriatal serotonergic pathways. Brain Res. 1976;106:257-69.

11. Ghosh MN, Parvathy S. The effect of cyproheptadine on water and food intake and on body weight in the fasted adult and weanling rats. Br J Pharm. 1973;48: 328P-9P.

12. Saller CF, Stricker EM. Hyperphagia and increased growth in rats after intraventricular injection of 5,7-dihydroxytryptamine. Science. 1976;192:385-7.

13. Smith SR, Weissman NJ, Anderson CM, Sanchez M, Chuang E, Stubbe S, et al. Multicenter, placebo-controlled trial of lorcaserin for weight management. $\mathrm{N}$. Engl J Med. 2010;363:245-56

14. D'agostino G, Lyons D, Cristiano C, Lettieri M, Olarte-Sanchez C, Burke LK, et al. Nucleus of the solitary tract serotonin $5-\mathrm{HT} 2 \mathrm{C}$ receptors modulate food intake. Cell Metab. 2018;28:619-30.e615.

15. Xu P, He Y, Cao X, Valencia-Torres L, Yan X, Saito K, et al. Activation of serotonin $2 \mathrm{C}$ receptors in dopamine neurons inhibits binge-like eating in mice. Biol Psychiatry. 2017;81:737-47.

16. Blumenthal SA, Pratt WE. d-Fenfluramine and lorcaserin inhibit the binge-like feeding induced by mu-opioid receptor stimulation of the nucleus accumbens in the rat. Neurosci Lett. 2018;687:43-8.

17. Connolly HM, Crary JL, McGoon MD, Hensrud DD, Edwards BS, Edwards WD, et al. Valvular heart disease associated with fenfluramine-phentermine. N. Engl J Med. 1997;337:581-8

18. FDA. Safety clinical trial shows possible increased risk of cancer with weight-loss medicine Belviq, Belviq XR (lorcaserin). 2020. https://www.fda.gov/drugs/drugsafety-and-availability/safety-clinical-trial-shows-possible-increased-risk-cancerweight-loss-medicine-belviq-belviq-xr. Acessed 13 Feb 2020.

19. Elmquist JK, Coppari R, Balthasar N, Ichinose M, Lowell BB. Identifying hypothalamic pathways controlling food intake, body weight, and glucose homeostasis. J Comp Neurol. 2005;493:63-71.

20. Morton GJ, Cummings DE, Baskin DG, Barsh GS, Schwartz MW. Central nervous system control of food intake and body weight. Nature. 2006;443:289-95.

21. Stuber GD, Hopf FW, Tye KM, Chen BT, Bonci A. Neuroplastic alterations in the limbic system following cocaine or alcohol exposure. Curr Top Behav Neurosci. 2010;3:3-27.

22. Epstein DH, Preston KL, Stewart J, Shaham Y. Toward a model of drug relapse: an assessment of the validity of the reinstatement procedure. Psychopharmacology. 2006;189:1-16

23. Pignatelli $M$, Bonci $A$. Role of dopamine neurons in reward and aversion: a synaptic plasticity perspective. Neuron. 2015;86:1145-57.

24. Szczypka MS, Kwok K, Brot MD, Marck BT, Matsumoto AM, Donahue BA, et al. Dopamine production in the caudate putamen restores feeding in dopaminedeficient mice. Neuron. 2001;30:819-28.

25. Denis RGP, Joly-Amado A, Webber E, Langlet F, Schaeffer M, Padilla SL, et al. Palatability can drive feeding independent of AgRP neurons. Cell Metab. 2017;25:975.

26. Berglund ED, Liu C, Sohn JW, Liu T, Kim MH, Lee CE, et al. Serotonin 2 C receptors in pro-opiomelanocortin neurons regulate energy and glucose homeostasis. Clin Investig. 2013;123:5061-70.

27. Kocaman N, Kuloglu T. Expression of asprosin in rat hepatic, renal, heart, gastric, testicular and brain tissues and its changes in a streptozotocin-induced diabetes mellitus model. Tissue Cell. 2020;66:101397.

28. Unger EK, Keller JP, Altermatt M, Liang R, Matsui A, Dong C, et al. Directed evolution of a selective and sensitive serotonin sensor via machine learning. Cell. 2020;183:1986-2002.e1926.

29. Tong $Q$, Ye CP, Jones JE, Elmquist JK, Lowell BB. Synaptic release of GABA by AgRP neurons is required for normal regulation of energy balance. Nat Neurosci. 2008;11:998-1000.

30. Madisen L, Zwingman TA, Sunkin SM, Oh SW, Zariwala HA, Gu H, et al. A robust and high-throughput Cre reporting and characterization system for the whole mouse brain. Nat Neurosci. 2010;13:133-40.
31. Schweizer $C$, Balsiger S, Bluethmann $H$, Mansuy IM, Fritschy JM, Mohler $H$, et al. The gamma 2 subunit of $\mathrm{GABA}(\mathrm{A})$ receptors is required for maintenance of receptors at mature synapses. Mol Cell Neurosci. 2003;24:442-50.

32. Deignan J, Luján R, Bond C, Riegel A, Watanabe M, Williams JT, et al. SK2 and SK3 expression differentially affect firing frequency and precision in dopamine neurons. Neuroscience. 2012;217:67-76.

33. Qu N, He Y, Wang C, Xu P, Yang Y, Cai X, et al. A POMC-originated circuit regulates stress-induced hypophagia, depression, and anhedonia. Mol Psychiatry. 2020;25: 1006-21.

34. Morecroft I, White K, Caruso P, Nilsen M, Loughlin L, Alba R, et al. Gene therapy by targeted adenovirus-mediated knockdown of pulmonary endothelial Tph1 attenuates hypoxia-induced pulmonary hypertension. Mol Ther. 2012;20:1516-28.

35. Mazzone CM, Liang-Guallpa J, Li C, Wolcott NS, Boone $M H$, Southern $M$, et al High-fat food biases hypothalamic and mesolimbic expression of consummatory drives. Nat Neurosci. 2020;23:1253-66.

36. Cao X, Xu P, Oyola MG, Xia Y, Yan X, Saito K, et al. Estrogens stimulate serotonin neurons to inhibit binge-like eating in mice. J Clin Invest. 2014;124:4351-62.

37. Liu T, Kong D, Shah BP, Ye C, Koda S, Saunders A, et al. Fasting activation of AgRP neurons requires NMDA receptors and involves spinogenesis and increased excitatory tone. Neuron. 2012;73:511-22.

38. Fenselau H, Campbell JN, Verstegen AM, Madara JC, Xu J, Shah BP, et al. A rapidly acting glutamatergic ARC $\longrightarrow$ PVH satiety circuit postsynaptically regulated by alpha-MSH. Nat Neurosci. 2017;20:42-51.

39. Li C, Navarrete J, Liang-Guallpa J, Lu C, Funderburk SC, Chang RB, et al. Defined paraventricular hypothalamic populations exhibit differential responses to food contingent on caloric state. Cell Metab. 2019;29:681-94 e685.

40. Li Y, Zhong W, Wang D, Feng Q, Liu Z, Zhou J, et al. Serotonin neurons in the dorsal raphe nucleus encode reward signals. Nat Commun. 2016;7:10503.

41. Lerner TN, Shilyansky C, Davidson TJ, Evans KE, Beier KT, Zalocusky KA, et al. Intact-brain analyses reveal distinct information carried by SNc dopamine subcircuits. Cell. 2015;162:635-47.

42. Leinninger GM, Opland DM, Jo YH, Faouzi M, Christensen L, Cappellucci LA, et al. Leptin action via neurotensin neurons controls orexin, the mesolimbic dopamine system and energy balance. Cell Metab. 2011;14:313-23.

43. Ren J, Friedmann D, Xiong J, Liu CD, Ferguson BR, Weerakkody T, et al. Anatomically defined and functionally distinct dorsal raphe serotonin sub-systems. Cell. 2018;175:472-87.e420.

44. Ren J, Isakova A, Friedmann D, Zeng J, Grutzner SM, Pun A, et al. Single-cell transcriptomes and whole-brain projections of serotonin neurons in the mouse dorsal and median raphe nuclei. Elife. 2019;8:8.

45. Zhan C, Zhou J, Feng Q, Zhang JE, Lin S, Bao J, et al. Acute and long-term suppression of feeding behavior by POMC neurons in the brainstem and hypothalamus, respectively. J Neurosci. 2013;33:3624-32.

46. Aponte $Y$, Atasoy D, Sternson SM. AGRP neurons are sufficient to orchestrate feeding behavior rapidly and without training. Nat Neurosci. 2011;14:351-5.

47. Krashes MJ, Koda S, Ye C, Rogan SC, Adams AC, Cusher DS, et al. Rapid, reversible activation of AgRP neurons drives feeding behavior in mice. J Clin Investig. 2011;121:1424-8

48. Fink KB, Gothert M. 5-HT receptor regulation of neurotransmitter release. Pharm Rev. 2007;59:360-417.

49. Atasoy D, Betley JN, Su HH, Sternson SM. Deconstruction of a neural circuit for hunger. Nature. 2012;488:172-7.

50. Lorez M, Benke D, Luscher B, Mohler H, Benson JA. Single-channel properties of neuronal GABAA receptors from mice lacking the 2 subunit. J Physiol. 2000;527:11-31.

51. Wulff $P$, Goetz $T$, Leppä E, Linden AM, Renzi M, Swinny JD, et al. From synapse to behavior: rapid modulation of defined neuronal types with engineered GABAA receptors. Nat Neurosci. 2007;10:923-9.

52. Stocker $M$, Pedarzani $P$. Differential distribution of three $\mathrm{Ca}(2+)$-activated $\mathrm{K}(+)$ channel subunits, SK1, SK2, and SK3, in the adult rat central nervous system. Mol Cell Neurosci. 2000;15:476-93.

53. He Y, Shu G, Yang Y, Xu P, Xia Y, Wang C, et al. A small potassium current in AgRP/ NPY neurons regulates feeding behavior and energy metabolism. Cell Rep. 2016;17:1807-18.

54. Kong D, Dagon Y, Campbell JN, Guo Y, Yang Z, Yi X, et al. A postsynaptic AMPK$>$ p21-activated kinase pathway drives fasting-induced synaptic plasticity in AgRP. Neurons Neuron. 2016;91:25-33.

55. Elmquist JK, Elias CF, Saper CB. From lesions to leptin: hypothalamic control of food intake and body weight. Neuron. 1999;22:221-32.

56. Heisler LK, Lam DD. An appetite for life: brain regulation of hunger and satiety. Curr Opin Pharm. 2017:37:100-6.

57. Heisler LK, Jobst EE, Sutton GM, Zhou L, Borok E, Thornton-Jones Z, et al. Serotonin reciprocally regulates melanocortin neurons to modulate food intake. Neuron. 2006;51:239-49. 
58. Heisler LK, Cowley MA, Tecott LH, Fan W, Low MJ, Smart JL, et al. Activation of central melanocortin pathways by fenfluramine. Science. 2002;297:609-11.

59. Xu Y, Berglund ED, Sohn JW, Holland WL, Chuang JC, Fukuda M, et al. 5-HT2CRs expressed by pro-opiomelanocortin neurons regulate insulin sensitivity in liver. Nat Neurosci. 2010;13:1457-9.

60. Xu Y, Jones JE, Kohno D, Williams KW, Lee CE, Choi MJ, et al. 5-HT2CRs expressed by pro-opiomelanocortin neurons regulate energy homeostasis. Neuron. 2008;60:582-9.

61. Doslikova B, Garfield AS, Shaw J, Evans ML, Burdakov D, Billups B, et al. 5-HT2C receptor agonist anorectic efficacy potentiated by 5 -HT1B receptor agonist coapplication: an effect mediated via increased proportion of proopiomelanocortin neurons activated. J Neurosci. 2013;33:9800-4.

62. Molineaux SM, Jessell TM, Axel R, Julius D. 5-HT1c receptor is a prominent serotonin receptor subtype in the central nervous system. Proc Natl Acad Sci USA. 1989;86:6793-7.

63. Jennings JH, Rizzi G, Stamatakis AM, Ung RL, Stuber GD. The inhibitory circuit architecture of the lateral hypothalamus orchestrates feeding. Science. 2013;341:1517-21.

64. Wu Z, Kim ER, Sun H, Xu Y, Mangieri LR, Li DP, et al. GABAergic projections from lateral hypothalamus to paraventricular hypothalamic nucleus promote feeding. J Neurosci. 2015;35:3312-8.

65. Sweeney P, Yang Y. An excitatory ventral hippocampus to lateral septum circuit that suppresses feeding. Nat Commun. 2015;6:10188.

66. Denis RG, Joly-Amado A, Webber E, Langlet F, Schaeffer M, Padilla SL, et al. Palatability can drive feeding independent of AgRP neurons. Cell Metab. 2015;22:646-57.

67. Duerrschmid C, He Y, Wang C, Li C, Bournat JC, Romere C, et al. Asprosin is a centrally acting orexigenic hormone. Nat Med. 2017;23:1444-53.

68. Cone JJ, McCutcheon JE, Roitman MF. Ghrelin acts as an interface between physiological state and phasic dopamine signaling. J Neurosci. 2014;34:4905-13.

69. Nectow AR, Schneeberger M, Zhang $H$, Field BC, Renier N, Azevedo $E$, et al. Identification of a brainstem circuit controlling feeding. Cell. 2017;170:429-42. e411.

70. Campos CA, Bowen AJ, Schwartz MW, Palmiter RD. Parabrachial CGRP neurons control meal termination. Cell Metab. 2016;23:811-20.

71. Aklan I, Sayar Atasoy N, Yavuz Y, Ates T, Coban I, Koksalar F, et al. NTS catecholamine neurons mediate hypoglycemic hunger via medial hypothalamic feeding pathways. Cell Metab. 2020;31:313-26.e315.

72. Correia PA, Lottem E, Banerjee D, Machado AS, Carey MR, Mainen ZF. Transient inhibition and long-term facilitation of locomotion by phasic optogenetic activation of serotonin neurons. Elife. 2017;6:6.

73. Nagai Y, Takayama K, Nishitani N, Andoh C, Koda M, Shirakawa H, et al. The role of dorsal raphe serotonin neurons in the balance between reward and aversion. Int J Mol Sci. 2020;21:6.

74. Liu Z, Zhou J, Li Y, Hu F, Lu Y, Ma M, et al. Dorsal raphe neurons signal reward through 5-HT and glutamate. Neuron. 2014;81:1360-74.

75. Garfield AS, Li C, Madara JC, Shah BP, Webber E, Steger JS, et al. A neural basis for melanocortin-4 receptor-regulated appetite. Nat Neurosci. 2015;18:863-71.

\section{ACKNOWLEDGEMENTS}

The investigators were supported by grants from the NIH (R01DK114279, R01DK109934, and R21NS108091 to QT; R01ES027544 and R01DK111436 to ZS; R00DK107008 to PX; R01DK109194 and R56DK109194 to QW; P01DK113954, R01DK115761, R01DK117281, and R01DK125480 to YX; R01DK120858 to QT and YX; K01DK119471 to CW; and P20GM135002 to YH), USDA/CRIS (51000-064-01 S to YX and QW), American Diabetes Association (1-17-PDF-138 to YH, 7-13-JF-61 to QW, and 1-15-BS-184 to QT), American Heart Association awards (16POST27260254 to
CW), the Pew Charitable Trust awards to QW (0026188), Baylor Collaborative Faculty Research Investment Program grants to QW, the Faculty Start-up grants from USDA/ ARS to QW, the Biotechnology and Biological Sciences Research Council (BB/ K001418/1 and BB/NO17838/1 to LKH), and the Medical Research Council (MC/PC/ 15077 to LKH). QW is the Pew Scholar of Biomedical Sciences and the Kavli Scholar. The anxiety tests (e.g., open-field test, light-dark test, and elevated plus maze test) were performed in the Mouse Neurobehavior Core, Baylor College of Medicine, which was supported by National Institutes of Health Grant No. P30HD024064. The Ad-iN/ WED virus was kindly provided by Dr. Martin Myers (University of Michigan). The AAV9-CBA-DIO-WGA-zsGreen virus was kindly provided by Dr. Richard Palmiter (University of Washington).

\section{AUTHOR CONTRIBUTIONS}

$\mathrm{YH}$ and $\mathrm{XC}$ were involved in experimental design and most of procedures, data acquisition and analyses, and writing the manuscript. $\mathrm{HL}, \mathrm{KMC}, \mathrm{PX}, \mathrm{YL}, \mathrm{CW}, \mathrm{MY}, \mathrm{YH}$, $\mathrm{HL}, \mathrm{CL}, \mathrm{TY}, \mathrm{YY}, \mathrm{KY}, \mathrm{JW}, \mathrm{RZ}$, and $\mathrm{CZ}$ assisted in surgical procedures and production of study mice. $\mathrm{FL}, \mathrm{ZS}, \mathrm{LH}, \mathrm{QW}$, and $\mathrm{QT}$ were involved in study design and writing the manuscript. GS and $Y X$ the guarantor of this work and, as such, had full access to all the data in the study and takes responsibility for the integrity of the data and the accuracy of the data analysis.

\section{Declarations}

\section{COMPETING INTERESTS}

The authors declare no competing interests.

\section{ADDITIONAL INFORMATION}

Supplementary information The online version contains supplementary material available at https://doi.org/10.1038/s41380-021-01220-z.

Correspondence and requests for materials should be addressed to G.S. or Y.X.

Reprints and permission information is available at http://www.nature.com/ reprints

Publisher's note Springer Nature remains neutral with regard to jurisdictional claims in published maps and institutional affiliations.

Open Access This article is licensed under a Creative Commons Attribution 4.0 International License, which permits use, sharing, adaptation, distribution and reproduction in any medium or format, as long as you give appropriate credit to the original author(s) and the source, provide a link to the Creative Commons license, and indicate if changes were made. The images or other third party material in this article are included in the article's Creative Commons license, unless indicated otherwise in a credit line to the material. If material is not included in the article's Creative Commons license and your intended use is not permitted by statutory regulation or exceeds the permitted use, you will need to obtain permission directly from the copyright holder. To view a copy of this license, visit http://creativecommons. org/licenses/by/4.0/.

(c) The Author(s) 2021 